Notre Dame Law School

NDLScholarship

Journal Articles

Publications

2006

\title{
Congressional Power and State Court Jurisdiction
}

Anthony J. Bellia

Notre Dame Law School, anthony.j.bellia.3@nd.edu

Follow this and additional works at: https://scholarship.law.nd.edu/law_faculty_scholarship

Part of the Torts Commons

\section{Recommended Citation}

Anthony J. Bellia, Congressional Power and State Court Jurisdiction, 94 Geo. L.J. 949 (2005-2006).

Available at: https://scholarship.law.nd.edu/law_faculty_scholarship/879

This Article is brought to you for free and open access by the Publications at NDLScholarship. It has been accepted for inclusion in Journal Articles by an authorized administrator of NDLScholarship. For more information, please contact lawdr@nd.edu. 


\title{
Congressional Power and State Court Jurisdiction
}

ANThony J. Bellia JR.*

\author{
TABLE OF CONTENTS
}

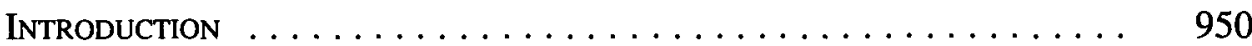

I. General Law Principles of Jurisdiction . . . . . . . . . . . 955

A. TRANSITORY ACTIONS .................. 956

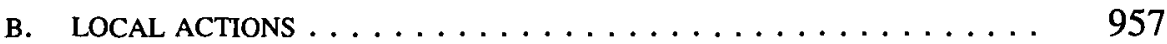

1. Actions Local by Nature . . . . . . . . . . . . . 957

a. Actions To Enforce Rights in Real Property . . . . . . 957

b. Penal Actions . . . . . . . . . . . . . . . . 959

2. Actions Made Local by Statute ... . . . . . . . . 965

II. The Historical Framework of Analysis . . . . . . . . . . . . 966

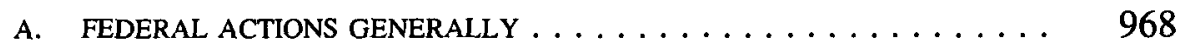

1. Arguments Within the General Law Framework . . . . . . 969

a. Interests of the Forum State . . . . . . . . . . 969

b. Interests of the United States . . . . . . . . . . 972

2. Arguments Outside the General Law Framework . . . . . 974

B. FEDERAL PENAL ACTIONS $\ldots \ldots \ldots \ldots \ldots \ldots$

1. Arguments Within the General Law Framework . . . . . 980

a. Interests of the Forum State . . . . . . . . 980

b. Interests of the United States . . . . . . . . . 981

2. Arguments Outside the General Law Framework . . . . . 988

III. ISSUES IN CONTEMPORARY APPLICATION . . . . . . . . . . . 991

A. STATE COURT JURISDICTION OF FEDERAL CRIMINAL ACTIONS . . . . 992

* Lilly Endowment Associate Professor of Law, Notre Dame Law School. @ 2006, Anthony J. Bellia Jr. I thank Rachel Barkow, Amy Barrett, Joe Bauer, Tricia Bellia, Michael Collins, Rick Garnett, John Nagle, Jim Pfander, Bob Pushaw, and participants in a faculty colloquium at the Notre Dame Law School for helpfuI comments on drafts of this Article; research librarian Patti Ogden for expert research assistance; and students Ben Carlson, Jessica Perazzelli, and Amy Van Dyke for excellent research assistance. 
B. STATE COURT JURISDICTION OF STATE LAW ACTIONS $\ldots \ldots \ldots$

1. Interests of a State Made a Lawful Forum ........ 1003

2. Interests of a State Made an Unlawful Forum . . . . . . 1004

C. LIMITATIONS OF THE POLITICAL SAFEGUARDS OF FEDERALISM . . . 1009

Conclusion . . . . . . . . . . . . . . . . . . . . . 1012

\section{INTRODUCTION}

Federal laws that purport to regulate state institutions raise what the Supreme Court has described as the "oldest question of constitutional law." The Court has confronted the question of what power Congress has to regulate state institutions in several different contexts. In Iandmark rulings in the 1990s, the Court held that Congress may not "commandeer" state legislatures or executive officials to enforce federal regulatory schemes. ${ }^{2}$ The Court also held that Congress may not subject states to suits in federal or state courts under its Article I powers because states have sovereign immunity that Congress may not abrogate. $^{3}$

There is one area of congressional power over state institutions, however, that the Supreme Court to date has largely left unchecked: Congress's power over state courts. In 1947 in Testa v. Katt, the Suprene Court held that a state court had a constitutional duty to enforce a federal action for civil penalties in the exercise of the state court's regular jurisdiction. ${ }^{4}$ In its recent anticommandeering jurisprudence, the Court went out of its way to explain that Congress does not unconstitutionally commandeer state courts wben it requires them to enforce certain actions that Congress has created. ${ }^{5}$

Though the Court has never struck down a federal statute requiring state courts to exercise jurisdiction over federal actions, there remain significant unanswered questions regarding the constitutional relationship between congressional power and state court jurisdiction. The Supreme Court has repeatedly suggested that there are limits on Congress's power to regulate the jurisdiction of state courts. In Testa, the Court held that a state court must enforce a federal action if it has "jurisdiction adequate and appropriate under established local

1. New York v. United States, 505 U.S. I 44,149 (1992).

2. See Printz v. United States, 521 U.S. 898, 929 (1997) (holding that Congress may not "commandeer" state executive officials to enforce a federal regulatory program); New York, 505 U.S. at 175 (holding that Congress may not "commandeer" state legislatures to enact a federal regulatory program).

3. See Alden v. Maine, 527 U.S. 706, 754 (I999) (holding that Congress may not subject states to suits in state courts under its Article I powers); Seminole Tribe of Fla. v. Florida, 517 U.S. 44, 75 (1996) (holding that Congress may not subject states to suits in federal court under its Article I powers).

4. See Testa v. Katt, 330 U.S. 386, 394 (I947).

5. See Printz, 52I U.S. at 907 (explaining that although Congress may not direct state executives to enforce federal law, the Constitution allows Congress to impose certain obligations on state judges to do so); New York, 505 U.S. at I78-79 (same). 
law to adjudicate [the] action." Thirty-five years earlier, in Mondou $v$. New York, New Haven, \& Hartford Railroad Co. ${ }^{7}$ the Court, holding that state courts must enforce actions arising under the Federal Employers' Liability Act ("FELA"), specifically noted that Congress had not attempted in FELA "to enlarge or regulate the jurisdiction of state courts." More recently, in 1999 in Alden v. Maine, the Court explained that Congress generally "may require state courts of adequate and appropriate jurisdiction to enforce federal prescriptions." In each of these cases, the Court suggested that Congress's power to regulate the jurisdiction of state courts may be subject to structural constitutional limitations.

Since the time that the Constitution was ratified, questions have arisen regarding the constitutional power of Congress to require or allow state courts to exercise jurisdiction over certain kinds of actions. Some of these questions remain unresolved by the Supreme Court today. One such question is whether Congress may require (or even allow) state courts to hear federal criminal actions. In the last decade, certain scholars have renewed calls for Congress to consider such action, ${ }^{10}$ as has the Judicial Conference of the United States. ${ }^{11}$ Other questions involving congressional power to regulate state court jurisdiction are emerging for the first time today. One such question is whether Congress may regulate state court jurisdiction in state law cases. The Lawsuit Abuse Reduction Act of 2005 ("LARA"), ${ }^{12}$ a "tort reform" proposal, would require plaintiffs to bring state law personal injury claims in particular state courts. ${ }^{13}$ Members of Congress have opposed this Act on federalism grounds. In the words of one, the Act is "an unprecedented intrusion into Federalism."14

Identifying judicially enforceable limitations on congressional power based

6. Testa, 330 U.S. at 394.

7. 223 U.S. 1 (1912).

8. Id. at 56; see also Claflin v. Houseman, 93 U.S. 130, 137 (I876) (explaining that federal rights of action are enforceable in state court, so Iong as the state court is "competent to decide rights of the like character and class").

9. Alden v. Maine, 527 U.S. 706, 752 (1999) (internal quotation marks, citations, and brackets omitted) (emphasis added).

10. See, e.g., Sara Sun Beale, Too Many and Yet Too Few: New Principles To Define the Proper Limits for Federal Criminal Jurisdiction, 46 Hastings L.J. 979, 1010-15 (1995); Thomas Mengler, The Sad Refrain of Tough on Crime: Some Thoughts on Saving the Federal Judiciary from the Federalization of State Crime, 43 U. KAN. L. REv. 503, 535-40 (1995).

11. Specifically, the Judicial Conference has proposed that "federal prosecutions of local drug activity and some violent crime could take place in state court, either by the U.S. Attorney's Office (through cross-designation) or the state's attorney." Judicial Conference of the U.S., LoNG RANGE Plan for the Federal Courts 27 (1995).

12. In the last Congress, the House of Representatives passed the Lawsuit Abuse Reduction Act of 2004, H.R. 4571, 108th Cong. (2004); the bill has been reintroduced in the current Congress. See Lawsuit Abuse Reduction Act of 2005, H.R. 420, 109th Cong. (2005).

13. See id. §4(a).

14. Congressman Howard Berman has argued that LARA's regulation of state court venue is "an unprecedented intrusion into Federalism" insofar as it seeks "to regulate how State laws, State legislatures and State courts decide venue issues on personal injury cases handled in State courts." H.R. REP. No. 108-682, at 85 (2004). 
on state sovereignty interests, if indeed any such limitations exist, is a difficult problem of constitutional law. ${ }^{15}$ In considering the relationship between congressional power and state court jurisdiction, courts and scholars should take account of whatever discernable historical understandings of the constitutional structure there may be in this regard. Historical understandings have played a central role in the Court's recent constitutional analyses of federalism issues. Both majorities and dissents have claimed fidelity to historical understandings in expressing opinions on the constitutionality of congressional regulations implicating federalism concerns. ${ }^{16}$ Indeed, Justice Stephen Breyer recently remarked that "all of us" on the Supreme Court "are interested in history" in deciding cases. ${ }^{17}$ Even those who reject the existence of any structural limitations on congressional power should take account of historical understandings in determining whether, as a prudential matter, Congress should regulate state court jurisdiction. Certain scholars have argued that the so-called political safeguards of federalism - the political power that the States have in the operation of the federal government to protect their own autonomy-are the primary

15. Had the Supreme Court not come to recognize the expansive congressional power to regulate "commerce" that it has in the last century, Congress may not have enacted much of the legislation that has raised vexing constitutional federalism questions for the Court.

16. This is true in the cases involving sovereign immunity, see, e.g., Alden v. Maine, 527 U.S. 706, 713 (1999) ("[T]he Constitution's structure, its history, and the authoritative interpretations by this Court make clear [that] the States' immunity from suit is a fundamental aspect of the sovereignty which the States enjoyed before the ratification of the Constitution, and which they retain today."); id. at 761 (Souter, J., dissenting) ("There is ... no evidence that any concept of inherent sovereign immunity was understood historically to apply when the sovereign sued was not the font of the law."); the scope of the Commerce Clause, see, e.g., United States v. Morrison, 529 U.S. 598, 613 (1995) ("[1]t is difficult to perceive any limitation on federal power, even in areas such as criminal law enforcement or education where States historically have been sovereign.") (quoting United States v. Lopez, 514 U.S. 549, 564 (1995)); id. at 641 (Souter, J., dissenting) ("Chief Justice Marshall[] . . construed the commerce power from the start with a breadth never yet exceeded.... This plenary view of the power has either prevailed or been acknowledged by this Court at every stage of our jurisprudence.") (internal quotation marks and citation omitted); and cases addressing whether Congress may use state institutions as part of a federal regulatory program, see, e.g., Printz v. United States, 521 U.S. 898, 905 (1997) ("[T]he answer ... must be sought in historical understanding and practice, in the structure of the Constitution, and in the jurisprudence of this Court."); id. at 939 (Stevens, J., dissenting) ("This conclusion is firmly supported by the text of the Constitution, the early history of the Nation, decisions of this Court, and a correct understanding of the basic structure of the Federal Government.").

17. Justice Breyer remarked:

I believe that all of us-Justice Scalia, Justice O'Connor, Justice Thomas, the Chief, everyonehas in a sense quite a similar framework that fits most legal cases. All of us look to texts, all of us are interested in history, all of us are interested in tradition, all of us are interested in precedent, all of us, in fact, want to understand the value or purpose that underlie the law, and all of use are interested in how our decision--how it will turn out in terms of the consequences viewed through the prism of that value or purpose. But there are differences, I think, in the weights that different judges tend over time to give those elements in different cases.

Transcript of Discussion Between U.S. Supreme Court Justices Antonin Scalia and Stephen Breyer-AU Washington College of Law (Jan. 13, 2005), available at http://www.american.edu/media (select "Press Releases"; scroll to Jan. 14, 2005 press releases; select "Transcript of Discussion Between U.S. Supreme Court Justices Antonin Scalia and Stephen Breyer"). 
safeguards of federalism in the American constitutional scheme. ${ }^{18}$ Under their theories, congressional regulation of state court jurisdiction should pose no justiciable structural constitutional problem with Congress regulating state court jurisdiction in any way. ${ }^{19}$ On the prudential question of whether Congress should regulate state court jurisdiction, however, historical materials provide a trove of insights. If the political safeguards of federalism are real, federal officials solicitous of state autonomy interests, before deciding whether to regulate state court jurisdiction, ought to understand and consider the arguments that public officials historically have made for and against the constitutionality of federal regulation of state court jurisdiction.

The Supreme Court has taken three different approaches to analyzing, as a historical matter, whether congressional regulation of state institutions is constitutional. First, the Supreme Court has asked whether a federal statute unconstitutionally interferes with traditional state functions. This was the approach that the Court took in 1976 in National League of Cities v. Usery, when it held that Congress may not enforce minimum wage and overtime regulations "in areas of traditional governmental functions." ${ }^{20}$ As is well known, the Court later repudiated this approach in 1985 in Garcia v. San Antonio Metropolitan Transit Authority. ${ }^{21}$ Second, the Court has asked whether a federal statute unconstitutionally "commandeers" state institutions. This was the approach that the Court took in New York $v$. United States, when it held that Congress may not commandeer state legislatures to enact a federal regulatory program, ${ }^{22}$ and in Printz v. United States, when it held that Congress may not commandeer state executives to enforce a federal regulatory program. ${ }^{23}$ Third, the Court has asked whether a federal statute unconstitutionally interferes with state sovereignty interests that common law or general law principles recognized at the time of the Founding. This was the approach that the Court took in Seminole Tribe of Florida v. Florida, when it held that Congress could not abrogate sovereign immunity under an Article I power because the common law sovereign immunity of states inheres in the constitutional structure. ${ }^{24}$

18. See Larry D. Kramer, Putting the Politics Back into the Political Safeguards of Federalism, I00 Colum. L. REv. 2 I5 (2000); Herbert Wechsler, The Political Safeguards of Federalism: The Role of the States in the Composition and Selection of the National Government, 54 Colum. L. Rev. 543 (1954).

19. See Kramer, supra note I8, at 289 ("[F]rom Dred Scott to the New Deal to National League of Cities, the Justices' rare efforts to impose their views of the proper limits of federal power have been controversial failures that accomplished little other than to damage the Court's reputation."); Wechsler, supra note I8, at 559 ("[T]he Court is on weakest ground when it opposes its interpretation of the Constitution to that of Congress in the interests of the States."); $c f$. Edward L. Rubin \& Malcolm Feeley, Federalism: Some Notes on a National Neurosis, 41 UCLA L. Rev. 903, 909 ("The Supreme Court should never invoke federalism as a reason for invalidating a federal statute or as a principle for interpreting it.").

20. 426 U.S. 833,852 (I976).

2I. See 469 U.S. 528, 53 I (I985).

22. See 505 U.S. I 44,176 (1992).

23. See 521 U.S. 898, 935 (I997).

24. See 5I7 U.S. 44, 72-73 (1996). 
Which, if any, of these approaches ${ }^{25}$ should courts take to questions of congressional power over state court jurisdiction? During the Founding period and the decades that followed ratification, framers of the Constitution, participants in ratification debates, members of Congress, and state and federal judges, including those who wrote treatises-collectively, "public officials"-extensively discussed and debated questions of congressional power to allocate jurisdiction of federal law cases to state courts. To the extent that historical understandings matter (and they have mattered to the Court), the historical record sheds significant light on the question of how the Supreme Court should give content to its repeated suggestion that there are limits on federal power to regulate state court jurisdiction. First, the historical record reveals that during the Founding period and decades that followed ratification, public officials analyzed questions of congressional power to assign federal actions to state courts within a discernable legal framework. Specifically, they considered whether general law principles of jurisdiction-to wit, jurisdictional principles of the law of nations-operated within the structure of the Constitution as a limitation on congressional power to allow or require state courts to hear certain cases. They generally presumed that general jurisdictional principles defined the relationship between congressional power and state court jurisdiction unless a specific constitutional provision remade that relationship in some regard. Second, the framework within which public officials analyzed the relationship between congressional power and state court jurisdiction is akin to the approach that the Court has taken to questions of state sovereign immunity: Public officials characterized the sovereignty interests that a discernable source of law-the general law-identified as setting general bounds on congressional power, subject to exceptions that specific provisions of the Constitution authorized. Third, the framework that they employed was relatively workable. Certain legal standards that the Court has employed to define boundaries between federal and state authority have been notoriously unworkable, for example that Congress may not legislate in areas of "traditional state functions." 26 By contrast, the general law principles that defined the sovereign interests of states in adjudication were relatively clear and established in many circumstances.

This Article attempts to illuminate the framework within which framers, ratifiers, legislators, judges, and other public officials considered questions of congressional power over state court jurisdiction during the Founding period and decades that immediately followed. It also examines the ongoing viability of that framework relative to questions of congressional power to regulate state court jurisdiction that remain live today. The Article proceeds as follows.

25. Of course, these three approaches are not entirely analytically distinct from each other in all cases. In Alden, the Court, in holding on grounds of sovereign immunity that Congress may not subject states to suits in state courts, remarked that such a power would be one "to commandeer the entire political machinery of the State against its will." Alden v. Maine, 527 U.S. 706, 749 (1999).

26. In Garcia v. San Antonio Metropolitan Transit Authority, 469 U.S. 528 (1985), which rejected the "traditional state functions" standard, the Court deemed the standard "unworkable." Id. at 531. 
Part I explains the general law background that animated the arguments that public officials made about congressional power over state court jurisdiction during the Founding period and first decades of the American republic. Part II describes the specific arguments that public officials made regarding the relationship between congressional power and state court jurisdiction. Most arguments related to whether Congress constitutionally could allow or require state courts to adjudicate federal actions generally, and federal penal actions specifically. This Part does not argue that there was consensus on any specific answers to these questions. Rather, it discerns the framework within which these questions were considered. It shows how relevant actors premised constitutional arguments upon either general law jurisdictional principles or constitutional provisions interpreted to override general law principles.

Part III examines the application of this general-law-based framework to questions of congressional power over state court jurisdiction that remain unresolved today. In particular, this Part examines the framework's application to questions of congressional power to (l) assign jurisdiction of federal criminal cases to state courts, and (2) regulate state court jurisdiction in state law cases. The analysis provides seemingly straightforward answers to certain questions. To other questions, the analysis provides no straightforward answers, but rather identifies the points on which the questions turn, some involving great difficulties. Notwithstanding the difficulties, Part III argues that one should not lightly reject the framework that historically shaped debates about such questions in favor of exclusive reliance on the political safeguards of federalism. As a historical matter, there appears to have been widespread acknowledgement during the Founding period and subsequent few decades that judicially enforceable limitations on congressional power with respect to state court jurisdiction exist. Moreover, as a functional matter, certain federal regulations of state court jurisdiction could operate to weaken the political safeguards of federalism themselves.

\section{General Law Principles of Jurisdiction}

In making constitutional arguments about congressional power to allocate jurisdiction to state courts, delegates to the Federal Convention, participants in ratification debates, courts, and legislators routinely invoked general law principles of jurisdiction. In the late eighteenth and early nineteenth centuries, general law, or the law of nations, governed matters that courts today categorize as matters of commercial law, admiralty and maritime law, private international law, and most significantly for present purposes, conflict of laws. ${ }^{27}$ General law was recognized to exist by virtue of transnational custom and practice and was distinguishable from "local" law, which governed matters such as realty, pro-

27. See Randall Brdwell \& Ralph U. Whitten, The Constttution and the Common law: The Decline of the Doctrines of Separation of Powers and Federalism 5I-53 (1977) (describing how these areas of law were considered to be outgrowths of the law of nations). 
bate, and procedure..$^{28}$ In what today we call the conflicts area, the law of nations deemed sovereignty to entail certain jurisdictional prerogatives. To understand these prerogatives - and how arguments about congressional power over state court jurisdiction related to them-it is necessary to appreciate the distinction that the law of nations drew between transitory and local actions.

\section{A. TRANSITORY ACTIONS}

As a matter of general law, a nation had power to exercise jurisdiction over an action for personal injuries even if it arose in another nation. In effect, a plaintiff could bring an action for personal injuries wherever the defendant could be found. Courts and treatise-writers referred to such actions as "transitory." ${ }^{29}$ Examples of transitory actions were actions for assault, battery, false imprisonment, defamation, or debt-recovery. ${ }^{30}$ The law of nations understood courts to have the power to enforce transitory actions on the ground that the judicial power of a nation extended "indiscriminately to" the legal relations of all "in the territory," citizens and non-citizens alike. ${ }^{31}$ Thus, a plaintiff could sue a non-citizen of State $A$ in the courts of State $A$ so long as the defendant was present in State $A$. A plaintiff could sue a citizen of State $A$ in the courts of State $A$ regardless of whether the citizen was present or absent from State $A$, as the general law recognized a sovereign to have jurisdiction over the legal relations of its citizens no matter where they were. ${ }^{32}$ This power of a sovereign to

28. For discussions of the distinction, see Patrick J. Borchers, The Origins of Diversity Jurisdiction, the Rise of Legal Positivism, and a Brave New World for Erie and Klaxon, 72 Tex. L. Rev. 79, 111-15 (1993); William A. Fletcher, The General Common Law and Section 34 of the Judiciary Act of 1789: The Example of Marine Insurance, 97 HARv. L. REv. 1513, 1527-28 (1984).

29. See William Blackstone, 3 Commentaries *294 ("[I]n transitory actions . . the plaintiff may declare in what country he pleases ...."); 1 Joseph ChITtY, A TrEatise on the Parties to Actions, THE Forms of ACTION, AND ON PLEADING 243 (1828) ("In all actions for injuries ex delicto to the person or to personal property, the venue is in general transitory ...."); 1 SIR JOHN COMYNS, A DIGEST OF THE LAws OF ENGLAND 159 (4th ed. 1800) ("When an action is for a transitory thing, it may be brought in any county ... ."); Henry John Stephen, A Treatise on the Principles of Pleading in Civil Actions 306 (1824) ("An action is ... transitory, if any principal fact be of the transitory kind."); JOSEPH STORY, COMMENTARIES ON THE CONFlict OF LAWS 466 (I834) ("[B]y the common law personal actions, being transitory, may be brought in any place, where the party defendant can be found.").

30. See 3 Blackstone, supra note 29, at *384 (describing examples); 1 CHTTY, supra note 29, at 243 (same); 1 ComYNs, supra note 29, at 159 (same).

31. Georg Friedrich von Martens, Summary of the Law of Nations 102 (William Cobbett trans., Thomas Bradford 1795).

32. Joseph Story explained in his famous treatise on the conflict of laws that "[i]n regard to [citizens], while within the territory of their birth, or adopted allegiance, the jurisdiction of the sovereignty over them is complete and irresistible. It cannot be controlled; and it ought to be respected everywhere." STORY, supra note 29, at 451. Regarding citizens absent from the territory of a state, Story explained:

It is true, that nations generally assert a claim to regulate the rights, duties, obligations, and acts of their own citizens, wherever they may be domiciled. And, so far as these rights, duties, obligations, and acts afterwards come under the cognizance of the tribunals of the sovereign power of their own country, either for enforcement, or for protection, or for remedy, there may be no just ground to exclude this claim.

Id. 
exercise jurisdiction over transitory actions served, as a Virginia court explained it in 1815, "interests of commerce" and "mutual advantages" to all nations. ${ }^{33}$ The power that the law of nations recognized in one sovereign to enforce actions arising under the laws of another was indeed a power and not a duty, albeit a power that sovereigns generally, but not without exception, exercised in the interests of comity. ${ }^{34}$

\section{B. LOCAL ACTIONS}

The law of nations distinguished local actions from transitory actions. Under general principles, one sovereign did not have power to exercise jurisdiction over an action that was local to another sovereign. The general law recognized certain actions to be universally local by nature, and a hmited power in sovereigns to render actions local by statute.

\section{Actions Local by Nature}

Actions local by nature included actions for the enforcement of certain rights relating to real property and penal actions. The local nature of penal actions is most relevant to questions of congressional power over state court jurisdiction that arose during the Founding period and the decades that followed. Accordingly, this section provides a brief description of the local nature of actions to enforce rights in real property, followed by a more detailed description of the local nature of penal actions.

a. Actions To Enforce Rights in Real Property. Actions to enforce real property rights were local. In other words, a plaintiff had to bring an action to establish rights in real property in the jurisdiction in which the property was

33. Jackson v. Rose, 4 Va. (2 Va. Cas.) 34, 36 (I8I5). See I James Kent, Commentaries on American LAw 3-4 (2d ed. I832) (describing law of nations as governing "a community of nations, united by ... the mutual advantages of commercial intercourse").

34. As Joseph Story explained, "It must be admitted as a general proposition, that the laws of one country cannot in themselves have any extraterritorial force; and whatever force they are permitted to have in foreign countries must depend upon the comity of nations, regulated by a sense of their own interests, and public convenience." LeRoy v. Crowninshield, 15 F. Cas. 362, 366 (C.C.D. Mass. 1820) (No. 8,269); see also STORY, supra note 29, at 26 ("No nation can be justly required to yield up its own fundamental policy and institutions in favor of another."). Story explained, for example, that "[t]here are nations, indeed, which wholly refuse to take cognizance of controversies between foreigners, and remit them for rehef to their own domestic tribunals, or to that of the party defendant; and, especially, as to matters originating in foreign countries .... But this is a mere matter of municipal policy and convenience, and does not result from any principles of international law." Id. at 453. See also 2 KENT, supra note 33, at 58 "There is no doubt of the truth of the general proposition, that the laws of a country have no binding force beyond its territorial limits; and their authority is admitted in other states, not ex proprio vigore, but ex comitate."); HENRY WhEATON, ElEMENTS OF INTERNATIONAL LAW I13 (6th ed. 1855) ("[A]l1 the effect, which foreign laws can have in the territory of a State, depends absolutely upon the express or tacit consent of that State. A State is not obliged to allow the application of foreign laws within its territory, but may absolutely refuse to give any effect to them."). 
located. Commentators from Blackstone to Story recited this principle, ${ }^{35}$ as did English and American courts. ${ }^{36}$ Courts and commentators offered two primary justifications for this principle. First, as Joseph Story put it, "innumerable inconveniences" would arise if title to a particular real property interest were subject to potentially conflicting regulation by different states. ${ }^{37}$ Second, as English and American courts explained, only the executive authority of the jurisdiction in which property was located would have authority to enforce a judgment with respect to it. ${ }^{38}$

35. See 3 BLACKSTONE, supra note 29 , at *294 ("In local actions, where possession of land is to be recovered, or damages for an actual trespass, or for waste, \&c, affecting land, the plaintiff must lay his declaration or declare his injury to have happened in the very county and place that it really did happen...."); 1 CHITTY, supra note 29, at 241 (explaining with respect to venue that "[w]hen the cause of action could only have arisen in a particular place or county, it is local, and the venue must be laid therein," as "in real actions" and actions "though merely for damages, occasioned by injuries to real property"); 1 Comyns, supra note 29 , at 150 (explaining that "[e]very action for recovery of seisin, or possession of land, shall be brought in the county where the land lies"); STORY, supra note 29, at 463 ("In respect to immoveable property, every attempt of a foreign tribunal to found a jurisdiction over it, must, from the very nature of the case, be utterly nugatory, and its decree must be for ever incapable of execution in rem."); Joseph Story, A Selection of Pleadings in Civil actions 25 (2d ed. 1829) ("If a local action is brought in a wrong county, this may be pleaded in abatement of the plaintiff's writ, as well as to the jurisdiction."); WILliam TIDD, PRActical Forms 168 (1799) (providing, as a form of affidavit, in support of improper venue, "C.D. of, \&c. the above defendant, maketh oath and faith, that the plaintiff's cause of action (if any) arose in the county of $L$. and not in the county of M. (where the venue is laid) or elsewhere out of the said county of L").

36. For examples of Enghish cases, see Jeffries v. Duncombe, (1809) 103 Eng. Rep. 991,992 (K.B.) (Ellenborough, C.J.) ("This is not a local injury: the house indeed is local, but the imputation meant to be conveyed by the nuisance is not against the property, but against the man who occupies it."); Doulson v. Matthews, (1792) 100 Eng. Rep. 1143, 1144 (K.B.) (Buller, J.) ("It is now too late for us to inquire whether it were wise or politic to make a distinction between transitory and local actions: it is sufficient for the Courts that the law has settled the distinction, and that an action quare clausum fregit is local."); Mayor of Berwick v. Ewart, (1776) 96 Eng. Rep. 629, 630 (K.B.) (DeGrey, C.J.) ("All real and mixed actions are strictly speaking local; but not therefore local, because real. Personal actions may be made real by the way of declaring."); Rafael v. Verelst, (1776) 96 Eng. Rep. 621, 622 (K.B.) (DeGrey, C.J.) (explaining that the jurisdiction of "rights of real property" is local).

For examples of American cases, see Livingston v. Jefferson, I5 F. Cas. 660, 665 (C.C.D. Va. 1811) (No. 8411) (opinion of Marshall, J.) (explaiming that "an action of quare clausem fregit" is "a local action"); Tarlton v. Briscoe, $7 \mathrm{Ky}$. (4 Bibb) 73, 73 (1815) ("Were this a local action, then as the suit should be brought in the county where the cause of action arose ...."); Clarkson v. Gifford, 1 Cai. R. 5, $5 \mathrm{n.1}$ (N.Y. Sup. Ct. 1803) ("The common law principle is, that demands arising from privity of estate, are, in their nature, local, and must be sued for where the estate lies."); New York v. Dawson, 2 Johns. Cas. 335, 335-36 (N.Y. Sup. Ct. 1801) ("Actions founded on the privity of estate are local, as in debt by the assignee or devisee of the lessor, against the lessee, or by the lessor against the assignee of a lease, or in covenant by the grantee of the reversion, against the assignee of a lease.").

37. See STORY, supra note 29, at 467 (explaiming that the "inconveniences" of not having exclusive jurisdiction over property in one sovereign "would be innumerable, and would subject the property to the most distressing conflicts arising from opposing titles").

38. See Ambler v. Norton, 14 Va. 23, 51 (1809) (Roane, J.) (explaining that the laying of venue "is substantial when the action is in rem, as in ejectment; for there the Sheriff must deliver possession, which he could not do unless the venue was laid in the proper County"); Mayor of London v. Cole, (1798) 101 Eng. Rep. 1144, 1146 (K.B.) (Kenyon, C.J.) ("An action, the fruit of which is the delivery of the land itself, it necessarily local, because the possession of land situate in one county, cannot be delivered by the sheriff of another."); Mostyn v. Fabrigas, (1774) 98 Eng. Rep. 1021, 1030 (K.B.) 
b. Penal Actions. Penal actions also were local..$^{39}$ Under general law principles, one jurisdiction would not enforce the penal laws of another. In 1825, Chief Justice John Marshall famously wrote that "[t]he courts of no country execute the penal laws of another." ${ }^{, 40}$ Accordingly, penal actions, unlike transitory actions, did not follow the person. English and American courts regularly recited this principle, ${ }^{41}$ as did treatises and digests. ${ }^{42}$

(Mansfield, J.) (explaining that the laying of venue is "substantial ... where the proceeding is in rem, and where the effect of the judgment cannot be had if it is laid in the wrong place").

39. See Doulson, 100 Eng. Rep. at 1144 (Buller, J.) ("We may try actions here which are in their nature transitory, though arising out of a transaction abroad, but not such as are in their nature local."); Rafael, 96 Eng. Rep. at 622-23 (DeGrey, C.J.) ("Crimes are in their nature local, and the jurisdiction of crimes is local. And as to rights of real property, the subject being fixed and immoveable. But personal injuries are of a transitory nature, and sequuntur forum rei."); Mostyn, 98 Eng. Rep. at 1030 (Mansfield, J.) (recognizing "distinction between transitory actions and local actions for venue purposes").

40. The Antelope, 23 U.S. 66, 123 (1825); see also Rose v. Himley, 8 U.S. (4 Cranch) 241, 280 (1808) (Marshall, C.J.) (stating that "[t]his court, having no right to enforce the penal laws of a foreign country, cannot inquire into any infraction of those laws"). In addition to the penal law exception, some courts applied a "revenue law" exception to the general rule that they would enforce actions based on the laws of another state. Under the revenue law exception, the courts of State $A$ would not entertain an action by State $B$ to enforce a revenue law of State $B$. By all appearances the revenue law exception was not well estabhshed in the law of nations at the time of the American founding. In a thorough opinion filed in 1946, the Missouri Court of Appeals identified only two English cases that had recited any such specific principle before the Constitution was adopted, both of them in dicta. See State v. Rodgers, 193 S.W.2d 919, 921-22 (Mo. Ct. App. 1946); see also Thomas B. Stoel, Jr., The Enforcement of Foreign Non-Criminal Penal and Revenue Judgments in England and the United States, 16 INT'L \& Comp. L.Q. $663,671,674,676$ (1967) (observing that there was "no direct English authority on enforcement of revenue laws until 1909," that few American cases before 1930 considered wbether a state must enforce another state's revenue laws, and no American cases considered whether an American court had to enforce a foreign revenue law).

41. For English cases, see Wolff v. Oxholm, (1817) 105 Eng. Rep. 1177, 1180 (K.B.) ("[N]o country regards the penal laws of another."); Ogden v. Folliott, (1790) 100 Eng. Rep. 825,829 (K.B.) (opinion of Buller, J.) ("It is a general principle, that the penal laws of one country cannot be taken notice of in another."); Rafael, 96 Eng. Rep. at 622 (DeGrey, C.J.) ("Crimes are in their nature local, and the jurisdiction of crimes is local.").

For American cases, see Commonwealth v. Green, 17 Mass. 515 (1822) (reciting as "a maxim of general law, recognized by all nations ... [t]hat the penal laws of a country do not reach, in their effects, beyond the jurisdiction where they are established"); Scoville v. Canfield, 14 Johns. 338, 340 (N.Y. 1817) ("The penal acts of one state can have no operation in another state. Penal laws are strictly local, and affect nothing more than they can reach."); Simmons v. Commonwealth, 5 Binn. 617, 620 (Pa. 1813) (Yeates, J.) ("Offences are local in their nature, and must at common law be tried in the county where they were committed."); Sturgenegger v. Taylor, 5 S.C.L. 7, 7 (1811) ("[C]rimes, and rights of real property, are local ....").

42. See StoRy, supra note 29 , at 516 . Story explained:

The common law considers crimes as altogether local, and cognizable and punishable exclusively in the country, where they are committed. No other nation, therefore, has any right to punish them; or is under any obligation to take notice of, or to enforce any judgment, rendered in such cases by the tribunals having authority to hold jurisdiction within the territory, where they are committed.

Id. Cf. 1 ComyNs, supra note 29, at 156 (explaining that "a declaration or information on a penal statute shall be alleged in the county where the offence was done; or the county may be traversed"); $3 \mathrm{~A}$ Systematic ARRANGement of LoRd CoKe's First Institute 363 (J.H. Thomas ed., 1826) ("In all penal actions, it is a rule, that the venue must be laid in the particular county in which the offence is committed ...."). 
There is no question that criminal actions qualified as penal actions. Laws imposing sentences and monetary penalties in favor of the state for offenses against the public were unquestionably penal. Several courts and treatise-writers used the words "crime" or "offence" as synonymous with "penal" violation well into the nineteenth century. ${ }^{43}$

It is less certain, however, that a private action for noncompensatory damages would have qualified as a penal action in the late eighteenth century. Before the middle of the nineteenth century, there was not an extensive body of case law addressing whether private actions for noncompensatory damages (for instance, punitive or multiple damages) were penal actions. In various contexts, English courts held that private actions for noncompensatory actions were not penal. ${ }^{44}$ In the nineteenth century - as statutes providing noncompensatory damages proliferated, actions for interjurisdictional enforcement of them occurred more frequently, and the reporting of judicial decisions regularized-more cases appeared addressing whether such actions were penal under the law of nations. English courts generally maintained that penal actions were those brought to recover penalties that a defendant owed to the state, not actions that injured persons brought to recover statutory penalties. ${ }^{45}$ Some American courts held otherwise, resolving that actions brought by injured individuals for statutory noncompensatory damages were penal actions. ${ }^{46}$ The Supreme Court did not squarely confront this question until 1892, when it arose in Huntington $v$. Attrill. ${ }^{47}$ In Huntington, the Supreme Court explained that "[p]enal laws, strictly

43. See Scoville, 14 Johns. at 340 ("The defendant cannot take advantage of, nor expect this Court to enforce, the criminal laws of another state."); Simmons, 5 Binn. at 620 ("Offences are local in their nature ...."); Sturgenegger, 5 S.C.L. at 7 ("[C]rimes, and rights of real property, are local ...."); STORY, supra note 29, at 516 ("The common law considers crimes as altogether local, and cognizable and punishable exclusively in the country, where they are committed.").

44. See Woodgate v. Knatchbull, (1787) 100 Eng. Rep. 80, 84 (K.B.) ("[I]t has been held in many instances, that where a statute gives accumulative damages to the party grieved, it is not a penal action ... ."). In Myddleton v. Wynn, (1745) 125 Eng. Rep. 1339 (K.B.), for example, the Court had to decide whether a private action for double damages was remedial or punitive for purposes of determiming whether the venire was sufficient. The court held that the action was "remedial" insofar as it was a "satisfaction" to the plaintiff. Id. at 1341; $c f$. Hyde v. Cogan, (1781) 99 Eng. Rep. 445 (K.B.) (regarding what rule of construction to apply to the Riot Act, which provided that "the inhabitants of the hundred" were liable to certain acts, all justices agreed that the act was remedial as to the plaintiff).

45. In 1893, the Privy Council decided in its opimion in Huntington v. Attrill, [1893] A.C. 150, 157 (P.C. 1892) (appeal taken from Ont.), that "[a] proceeding, $m$ order to come within the scope of the rule, must be in the nature of a suit in favour of the State whose law has been infringed." Id. at 157. It made clear that statutory penalties are not "within the ... rule," unless recoverable by the state or a common informer. Id. at 158. Dicey thus would explain in his treatise on the conflict of laws: "[T]he essential characteristic, in short, of a penal action is that it should be an action on behalf of the government or the community, and not an action for remedying a wrong done to an individual." A.V. Dicey \& A. Berriedale Keith, The Conflict of Laws 231 (3d ed. 1922).

46. See, e.g., Indiana ex rel. Cone v. John, 5 Ohio 217, 220 (1831) (holding that action for statutory penalty for defendant's misfeasance in office was "founded upon a penal statute of the State of Indiana, whose authority is limited to the territory and courts of that state"). For a catalogue of such cases, see Peter Kutner, Judicial Identification of "Penal Laws" in the Conflict of Laws, 31 OKLA. L. REv. 590, 610-11 (1978).

47. 146 U.S. 657 (1892). 
and properly, are those imposing punishment for an offense committed against the state, and which, by the English and American constitutions, the executive of the state has the power to pardon." ${ }^{.48}$ In Huntington's most famous passage, the Court explained:

The question whether a statute of one state, which in some aspects may be called penal, is a penal law, in the international sense, so that it cannot be enforced in the courts of another state, depends upon the question whether its purpose is to punish an offense against the public justice of the state, or to afford a private remedy to a person injured by the wrongful act. ${ }^{49}$

Some courts interpreted Huntington to say that only actions brought by or on behalf of the state for public wrongs were penal actions; other state courts maintained that private actions for noncompensatory statutory damages were penal even after Huntington. ${ }^{50}$ The point is that courts did not uniformly hold from the late eighteenth century through the nineteenth century that private actions for noncompensatory damages were penal under the law of nations. Indeed, what eighteenth century English authority there was on this question suggested that private actions for noncompensatory damages were remedial rather than penal. ${ }^{51}$

The reasons that courts and treatise-writers provided to explain the penal law exception, whatever its breadth, were numerous. ${ }^{52}$ They related, first, to the interests of a forum state in not enforcing the penal laws of another state; and, second, to the sovereign prerogative of a state to exclusively enforce its own penal laws.

First, courts and treatise-writers described the interests that one state had in not enforcing the penal laws of another. As penal laws punished wrongs against

48. Id. at 667 .

49. Id. at 673-74.

50. See Kutner, supra note 46, at 611-17 (explaining how courts treated various kinds of actions for non-compensatory damages after Huntington).

51. See supra note 44 and accompanying text.

52. In a classic article, Robert Leflar explained a "variety of reasons" that might justify refusal in one state to enforce penal obligations arising in another. He summarized them as (1) "historical reasons based on the intensely local character of early legal systems"; (2) "respect for the sovereign rights and pretensions of foreign states and nations"; (3) "procedural difficulties"; (4) "local public policy opposing the type of claim presented for enforcement"; and (5) "practical inconveniences," such as the expense to a state of enforcing foreign penal claims, and hardship to the defendant from being tried away from where the relevant events likely occurred; and (6) "American constitutional guarantees to criminal defendants of the right to trial by jury in the vicinity of the offense." Robert A. Leflar, Extrastate Enforcement of Penal and Governmental Claims, 46 HARv. L. REv. 193, 201 (1932).

Our concern here is not with any reason that might be presented in support of a penal law exception, but with those reasons that courts and treatise-writers gave to explain the penal law exception during the Founding period and first few decades after ratification. As has been observed, Leflar did not address in any serious way the origins of the penal law exception as applied by early American courts. Mark W. Janis, The Recognition and Enforcement of Foreign Law: The Antelope's Penal Law Exception, 20 INT'L LAW. 303, 307 (1986). 
a particular state, a wrong against one state was of no concern to another state. ${ }^{53}$ Accordingly, a state had an interest in refusing to deploy its judicial process to enforce the penal laws of another state. In his Principles of Equity, Lord Kames explained, "The proper place for punishment, is where the crime is committed; and no society takes concern in any crime but what is hurtful to itself." 1774 case of Mostyn v. Fabrigas, ${ }^{55}$ Lord Mansfield wrote that a criminal matter must be tried in the country in which it arose because matters "against the peace of the king" were "merely local" ones. 56

A forum state not only had a general interest in reserving its judicial process for the enforcement of its own penal laws; it had a special interest in refusing to enforce penal laws of another state that contradicted its own public policy. Courts explained that the penal laws of one state might not reflect the public policy of another state. In Commonwealth v. Green, ${ }^{57}$ for example, the Supreme Judicial Court of Massachusetts explained that "many acts are made treason by positive enactments in one country, which would not be so in another. The infamy, therefore, consequent upon treason, ought not to pass beyond the country in which the crime is committed."58

Second, courts and treatise-writers described the enforcement of penal laws as the exclusive sovereign prerogative of the state where the penal violation occurred. The penal power of a state was said to encompass both the definition of a penal violation and the execution of a punishment for a penal violation. "Penal violations" and "punishments," unlike "transitory rights" and "civil liabilities," were inseverable. As Georg Friedrich von Martens explained in his famous treatise, The Law of Nations:

53. This was not the case, however, where one state sought to enforce a contract in the courts of another. See, e.g., United States v. Davy, Brayt. 146 (Vt. 1820) ("[N]o Court has refused the aid of the laws of the state, in collecting a debt due to the United States, founded merely on contract, [for] in such case the objections to enforcing a penal law of a different government do not exist.").

54. Henry Home, Lord Kames, PrinciPles of EQUITY 548 (4th ed. 1800).

55. (1774) 98 Eng. Rep. 1021 (K.B.).

56. Id. at 1030. This reasoning, he explained, might extend as well to certain civil matters between subjects of the same state:

[T] here are some cases that arise out of the realm, which ought not to be tried anywhere but in the country where they arise. [I]f two persons fight in France, and both happening casually to be here, one should bring an action of assault against the other, it might be a doubt whether such an action could be maintained here; because, though it is not a criminal prosecution, it must be laid to be against the peace of the king; but the breach of the peace is merely local, though the trespass against the person is transitory.

Id.; see also Wolff v. Oxholm, (18I7) 105 Eng. Rep. 1177, 1180 (K.B.) ("The penal laws of foreign countries are strictly local, and affect nothing more than they can reach and what can be seized by virtue of their authority.").

57. 17 Mass. 515 (1822).

58. Id. at 540. In Green, the court addressed whether the infamy of a conviction under a New York law disabled someone from testifying as a witness in a Massachusetts court. In holding that it did not, the court explained that " $[t]$ o hold a person incompetent on account of such a conviction, is to give effect to the conviction, and to enforce the punishment; and thus the penal laws of one country would reach into others, contrary to the principle above stated." Id. at 542. 
The end of civil society requires that the sovereign should have a right to forbid actions hurtful to the state and its members, to award penalties for such actions, apprehend and judge the criminals, and execute the sentence pronounced on them. These rights collectively taken, together with what is annexed to them, form the criminal power. This power extends to every one in the territory, whether subject or foreigner. ${ }^{59}$

Courts and treatise-writers offered several reasons why a state's penal power must encompass both proscribing an act and enforcing a penalty. The notion that "the punishment must fit the crime" captures the first of them. If the courts of State $A$ enforced the penal laws of State $B$ through the modes of proceeding and executions of State $A$, a disconnect might result between the act to be penalized and the penalty imposed. In other words, the law governing a penal action and the means of executing that law were understood to holistically serve the penal interests of the state. In the 1813 Pennsylvania case of Simmons $v$. Commonwealth, ${ }^{60}$ Justice Jasper Yeates wrote that Pennsylvania courts should not enforce a Delaware penal law on the ground that only a punishment inflicted by and under Delaware law would be "properly calculated" to enforce the Delaware law. ${ }^{61}$

A second reason why a state's penal power was understood to encompass both defining penal violations and punishing them was that the penalty that a state prescribed for a violation of its penal laws was something owed to that particular state. If State $A$ punished an offense against State $B$, State $A$ might obtain property that the defendant otherwise owed to State $B$. In the 1817 English admiralty case Le Louis, Sir William Scott made this point in his opinion for the English High Court of Admiralty. He explained that for a British court to enforce a French penal law by condemning a French vessel would be to confiscate property rightfully belonging to the French government:

59. MARTENS, supra note 31 , at 106-07.

60. 5 Binn. 617 (Pa. 1813).

61. Justice Yeates explained:

We must presume that the punishments annexed to crimes in Delaware, are properly calculated to promote the peace and good order of society in that state. If the penalty prescribed to a larceny is more severe than that in Pennsylvania for the like offence, then it is clear, that the defendant does not receive an adequate punishment upon his conviction here of the crime committed in Delaware; but if on the other hand, the punishment here is the most severe, it is also clear that upon such conviction, he would be subjected here to a greater penalty than the laws of the country where the offence was perpetrated, in such case inflicted.

Id. at 623-24 (opinion of Yeates, J.).

As Robert Leflar has observed, the sense in medieval times was that a crime could be punished only in, and according to the law of, the place of the offense because of both the community's responsibility for crimes committed within it, and the role of the jury in deciding based on their own knowledge of the facts. See Leflar, supra note 52, at 22 (citing I HoldswORTH, History OF ENGLish LAw 11-15, 317, 332 (3d ed. 1922)). As an execution of a criminal judgnient was possible only by and upon members of the community, the indivisibility of crime and execution has its roots in these times. 
Why is the British judge, professing, as he does, to apply French law, to assume cognisance for the mere purpose of directing that the penalties shall go to the British Crown and its subjects, which that law has appropriated to the French Crown and its subjects, thereby combining, in one act of this usurped authority, an aggression upon French property as well as upon French jurisdiction $?^{62}$

A third reason why a state's criminal power was understood to encompass both defining penal violations and punishing them related to a sovereign's power to pardon criminal offenses. The general law recognized all offenses to be pardonable, but only by the state against which an offense was committed. A state, however, could not exercise its pardon power beyond its own jurisdiction. ${ }^{63}$ In light of these principles, if State $A$ could enforce a crime committed against State $B$, no state would have power to pardon the offense. State $A$ could not pardon the offense, as the offender committed the offense against State $B$. State $B$ could not pardon the offense, as it could not exercise its pardon power extraterritorially. Accordingly, the offense would be unpardonable. In Commonwealth v. Green, the Massachusetts court found the need for a pardon power to exist "sufficient to show the reasonableness of limiting the penal effects of crime to the country whose laws have been violated."64

For any or all of these reasons, courts of one sovereign would not enforce the penal laws of another in the late eighteenth and early nineteenth centuries. Most

62. Le Louis, (1817) 165 Eng. Rep. 1464, 1479 (L.R.A. \& E.). For a more detailed analysis of the relationship.between the penal law exception and the Le Louis court's reliance on the impropriety of confiscating property rightfully under the jurisdiction of another state, see Janis, supra note 52, at 307.

63. In Commonwealth v. Green, the Supreme Judicial Court of Massachusetts explained:

It would seem to be consistent with sound principles, also, that, wherever there is a crime or punishment remaining in force, there slould be a power of pardon; but the act of pardon cannot operate upon an offence committed under another jurisdiction; nor can it extend beyond the jurisdiction of the offended sovereign.

17 Mass. at 542. As Martens explained, "[t]he right of cancelling a criminal suit, or of pardoning the criminal, can be exercised by no sovereign, out of the limits of his territory." MARTENs, supra note 31 , at 111 .

64. Green, 17 Mass. at 542. Yet another, though perhaps less recited, reason why a state's criminal power was understood to extend exclusively to enforcenent of crimes against it related to double jeopardy concerns. If one state enforced the penal laws of another state, the offender would be open to being placed in double jeopardy for the same crime. In Simmons v. Commonwealth, 5 Binn. 617 (Pa. 1813), Chief Justice Wilham Tilghman, invoking the principle that one state should not enforce the penal laws of another, explained that "[i]f we should punish him, he may be punished again in the state to which he may be sent; for certainly the courts of that state are not bound to pay any regard to our proceedings. A conviction here is no bar to an indictment there." Id. at 619. As Justice Jasper Yeates explained in his opinion in the same case:

Were it otherwise, the original unlawful act might be punished as often as the number of counties into which the criminal removed the goods; which would be a plain violation of the great principle of natural law and political justice, that a man should not be punished twice for the same offence.

Id. at 623 (opinion of Yeates, J.). 
of these reasons applied only to actions by or on behalf of the state for public wrongs: specifically, (1) that offenses against one sovereign were of no concern to another sovereign, (2) that a pardon power must exist for all offenses, and (3) that penalties were owed exclusively to the state against which an offense was committed. One reason for the penal law exception-namely that enforcement of a foreign penal law might conflict with public policy of the forum statecould apply to private actions for noncompensatory damages as well.

\section{Actions Made Local by Statute}

Even where the general law did not deem an action to be universally local by nature, certain courts recognized that, in limited circumstances, a sovereign could render an action local by statute. ${ }^{65}$ The act of a sovereign declaring an action local to itself created a tension between, on the one hand, the right of a state to create and define a cause of action, and, on the other hand, the power of a sovereign to exercise jurisdiction over the legal relations of all persons within its domains (that were not local by nature to another sovereign), even if those legal relations arose elsewhere. ${ }^{66}$

As a general matter, a sovereign's prerogative to exercise jurisdiction over those within its domains justified its exercising jurisdiction over actions arising under the laws of another sovereign (actions that were not local by nature), even if the other sovereign provided for jurisdiction of the action in its own courts. That said, there was one circumstance in which State $B$ would respect a law of State $A$ declaring courts of State $A$ to be the forum for enforcement of an otherwise transitory right arising under the laws of State $A$. If a statute of State $A$ both created a general liability regarding a local matter and a special remedy to be enforced in a forum of State $A$, a plaintiff could bring an action under that statute only in State $A .{ }^{67}$ In time, the Supreme Court explained that where a statute of State $A$ created a "right and remedy ... so united that the right cannot

65. For examples of English cases recognizing tlis, see Bruckshaw v. Hopkins, (1776) 98 Eng. Rep. 1157, 1157 (Ex. Cl1.) (Mansfield, J.) ("[I]f it slaall appear to be a Iocal action by statute, plaintiff will be nonsuited upon the opening."); Parker v. Elding, (1801) 102 Eng. Rep. 136, 137 (K.B.) (per curiam) (Kenyon, J.) (explaining that English courts must enforce Englisl statutes providing that an action is local). See also James Gould, A Treatise on the Principles of Pleading in Civil Actions I27 (Boston, Lilly and Wait 1832) (explaining that "where the action is given by statute, it may be either local or transitory, as the fair construction of the statute may appear to require"); $c f$. White v. Sanborn, 6 N.H. 220 (1833) (explaining that "[i]t often happens that an action, which is not in its nature local, is made so, in some respects, by the law of the place where the action is to be brought").

66. As Story explained, every sovereign could "rightfully exercise jurisdiction over all persons within its domains." STORY, supra note 29, at 452-54.

67. By way of example, Story explained, citing Lord Mansfield: "[S]o stock jobbing contracts, and the statutes thereupon, lave reference to our local funds. And so the statutes for restraining insurances upon the exportation of wool respect our own parts and shores." STORY, supra note 29, at 301. Accordingly, actions upon such statutes liad to be brouglit in the state that enacted the statute. Id.; $c f .1$ CHITTY, supra note 29, at 277 ("Some actions against particular persons, which otherwise would be transitory, must, by different statutes, be laid in the county where facts were committed, or the plaintiff will be nonsuited."). Along these lines, in Pickering v. Fisk, 6 Vt. 102 (1834), the Supreme Court of Vermont held that Vermont courts could not enforce an action on a bond that a New Hampshire statute 
be enforced except in the manner and before the tribunal designated by the act," ${ }^{68}$ State $B$ should decline to exercise jurisdiction. ${ }^{69}$ The theory was that for State $B$ to apply its own modes of proceeding would interfere with the sovereign prerogative of State $A$ to regulate its own judicial proceedings in local matters and thereby possibly modify the riglts of the parties as fixed by the governing law of State $A .^{70}$ In these limited circumstances, one sovereign might effectively render an otherwise transitory action local to its own courts.

With these background principles in mind, we can appreciate the terms in which questions of congressional power over state court jurisdiction were debated during the Founding era.

\section{The Historical Framework of ANALYsis}

Questions regarding the enforceability of federal law actions in state courts arose in the late eighteenth and early nineteenth centuries in various fora: the Federal Convention, ratification debates, congressional debates, judicial opinions, and legal treatises. The arguments that public figures made regarding these questions often drew upon, or at least fit comfortably with, general law principles of jurisdiction. Where arguments did not fit such general principles, they typically relied on constitutional provisions read to reject general jurisdictional principles in a particular regard. This Part explains how arguments about congressional power to allocate jurisdiction of actions arising under federal law to state courts generally either comported with general jurisdictional principles or relied on constitutional provisions asserted to override them.

Four preliminary points are in order regarding the purpose, methodology, organization, and conclusions of the analysis that follows. First, the purpose of this Part is to determine how, if at all, public officials commonly understood the power of Congress to assign jurisdiction of certain cases to state courts, and the duty of state courts to hear such cases during the Founding period and subsequent few decades. In other words, it is to determine, according to the best evidence available, whether those trained in the law or otherwise familiar with the legal operation of the Constitution shared any understanding of the constitutional relationship between congressional power and state court jurisdiction.

Second, two points on methodology are in order. First, this Part examines the

created because the New Hampshire statute was one "regulating the action of their tribunals, which, in its terms and character, is of local operation." $I$ d. at 109.

68. Tenn. Coal, Iron, \& R.R. Co. v. George, 233 U.S. 354, 359 (19I4).

69. Cf. Pollard v. Bailey, 87 U.S. 520, 527 (1874).

70. See, e.g., Pickering, $6 \mathrm{Vt}$. at 111 ("If such proceeding were tolerated, it might, and probably would, result in giving to the contract a totally different effect and operation from that contemplated by the law of New Hampshire, and intended by the parties."); see also 2 Francis Wharton, A TrEatise on the Conflict of Laws, or, Private International Law 1433-34 (George H. Parmele ed., 3d ed., Lawyers' Coop. Publ'g Co. 1905) (1872) ("[A] matter that is ordinarily regarded as pertaining to the remedy, and therefore governed by the lex fori, may become imcorporated as a part of the contract or cause of action; so that to apply the law of the forum with reference to the point would amount to a modification of the rights of the parties as fixed by the substantive law." (citations omitted)). 
historical record both before and after ratification for evidence of constitutional meaning. The political framework of constitutional debate regarding congressional power and state court jurisdiction shifted in various ways after ratification. For example, before ratification, Federalists and Anti-Federalists proffered understandings of the constitutional relationship between congressional power and state court jurisdiction in the context of whether the provisions of Article III should become law. After ratification, the Article III judicial power was a given and debate shifted to what jurisdiction Congress should give federal courts relative to state courts. Once Congress established the jurisdiction of federal courts, leaving jurisdiction of certain actions governed by federal law to state courts, constitutional questions arose regarding whether Congress had authority to require or even allow state courts to hear federal questions. State judges were not necessarily agnostic as to how these questions should be resolved. Notwithstanding, however, the shifting political contexts of debate and the political interests of participants in them, the framework within which constitutional questions regarding the relationship between congressional power and state court jurisdiction were debated remained constant before and after ratification. That arguments in different political contexts and toward different political ends generally proceeded within the same framework of analysis suggests an understanding on the part of those who made such arguments that the framework of analysis within which debate occurred was the proper framework of analysis.

The second point on methodology pertains to what qualifies as relevant evidence of constitutional understandings. This Part considers records of the Federal Convention, ratification debates, congressional acts and debates, judicial opinions, and legal treatises. The analysis proceeds from the premise, as judicial analyses of historical constitutional understandings generally do, that the relevant constitutional understandings are those held by individuals trained in the law or otherwise familiar with the legal operation of the Constitution. Regarding post-ratification evidence, some scholars and judges have given preference, in determining constitutional understandings, to official acts of the United States, for example, federal statutes. ${ }^{71}$ This preference may be warranted when there exists no serious or widespread objection to legally authorized government action. This preference is unwarranted, however, when government action is subject to regular contenıporaneous legal challenge on the grounds that the Constitution did not authorize it. Early acts of Congress assigning jurisdiction to state courts were subject to such challenges. Public officials questioned congressional power to require or even allow state court jurisdiction over certain actions from the Founding period until decades thereafter. Litigants

7I. See McCreary County v. ACLU, 125 S. Ct. 2722, 2754 (2005) (Scalia, J., dissenting) ("[I] have not relied upon ... 'mere proclamations and statements' of the Founders. I have relied primarily upon official acts and official proclamations of the United States or of the component branches of its Government ...."); Charles Warren, Federal Criminal Laws and the State Courts, 38 HaRv. L. REv. 545,545 (I925) (relying primarily on Acts of Congress to demonstrate constitutional understanding that Congress could confer jurisdiction of federal criminal actions on state courts). 
asserted, and some state courts held, that certain congressional regulations leaving jurisdiction of cases arising under federal law to state courts were unconstitutional. This Part does not attempt to distinguish "mainstream" historical actions from "outlier" historical actions. It presents all arguments on their own terms-whether made by Federalist or Anti-Federalist, Federalist or Republican, Anglophile or Francophile, federal official or state official, court majority or dissenting judge.

Third, a note is in order on the chosen manner of organization for this Part. This Part presents the available evidence not chronologically or according to the political interest of the speaker, but according the nature of the argument being made. The purpose of this Part is not to provide a political or chronological history of arguments about the relationship of congressional power to state court jurisdiction; it is, rather, to demonstrate that there was an order to the kinds of arguments advanced regarding the relationship between congressional power and state court jurisdiction, an order that reflects a shared legal understanding.

Finally, a note is in order on the conclusions that this Part attempts to draw from historical evidence. This Part does not purport to demonstrate-indeed, it does not demonstrate-that at the time of the Founding any particular constitutional question involving the relationship between congressional power and state court jurisdiction had a specific, generally understood, consensus answer. What it does demonstrate is that public officials made constitutional arguments about that relationship within a shared framework of analysis. The framework was that general law principles of jurisdiction defined the relationship between federal power and state court jurisdiction unless a specific constitutional provision overrode them in some regard.

The first section of this Part analyzes arguments about state court enforcement of actions arising under federal law generally. The second section analyzes arguments about actions arising under federal penal laws specifically. Questions involving federal penal actions warrant special treatment because they were the most intensively discussed questions regarding congressional power and state court jurisdiction both before and after ratification.

\section{A. FEDERAL ACTIONS GENERALLY}

Public officials discussed the enforceability of actions arising under federal law in state courts in both ratification debates about whether there should be a federal judiciary and, post-ratification, in congressional debates about what the structure of the federal judiciary should be. Alexander Hamilton famously described the enforceabihty of actions arising under federal law in state courts in general law jurisdictional terms in The Federalist No. 82. In arguing that state courts generally would have concurrent jurisdiction in cases arising under federal law, Hamilton explained: "The judiciary power of every government looks beyond its own local or mumicipal laws, and in civil cases lays hold of all subjects of hitigation between parties within its jurisdiction, though the causes of 
dispute are relative to the laws of the most distant part of the globe.,72 Moreover, he explained, "the State governments and the national governments" are "kindred systems" and "parts of ONE WHOLE."73 From this, he inferred "that the State courts would have a concurrent jurisdiction in all cases arising under the laws of Union, where it was not expressly prohibited."74 Most arguments that public officials made pre- and post-ratification regarding the enforceability of federal actions in state courts fit comfortably within the framework of general jurisdictional principles, or relied on constitutional provisions interpreted to override such principles.

\section{Arguments Within the General Law Framework}

As explained in Part I, general law jurisdictional principles accounted for sovereign interests of both the nation in which an action arose and the nation in which an action was brought. Likewise, arguments about state court jurisdiction over actions arising under federal law variously accounted for the sovereign interests of both individual states and the United States in the enforcement of federal law.

a. Interests of the Forum State. If, as Hamilton argued, state courts had the same judicial power to enforce actions arising under federal law as they had to enforce actions arising under foreign law, it was a power that they did not have a duty to exercise. ${ }^{75}$ Professor Michael Collins has argued that the predominant constitutional understanding at the time of the Founding was that Congress could not compel state courts to enforce federal actions. ${ }^{76}$ Under this view, notwithstanding the so-called Madisonian Compromise, if Congress found state court enforcement of federal law inadequate to serve the interests of the federal government, Congress's recourse was not to require state courts to enforce actions arising under federal law, but to create inferior federal courts to enforce them. This understanding comports with general law principles of jurisdiction regarding transitory actions: While one sovereign had power to enforce actions arising under the laws of another in the interests of comity, it did not have a duty to do so.

Prominent Federalists espoused this view in the early years of the Union. John Marshall wrote in Osborn v. Bank of the United States ${ }^{77}$ that state courts

72. The Federalist No. 82, at 555 (Alexander Hamilton) (Jacob E. Cooke ed., 1961).

73. Id. at 556 .

74. Id. at 555 .

75. See supra note 34 and accompanying text (explaining that under the law of nations a sovereign had the power, but not the duty, to enforce transitory actions arising under the laws of another sovereign).

76. See Michael G. Collins, Article III Cases, State Court Duties, and the Madisonian Compromise, 1995 Wis. L. REv. 39, 45 (summarizing article's extensive argument that the understanding of the Founding generation was "that states did not have to accept unwanted federal civil and criminal judicial business, and that Congress could not compel them to do so").

77. 22 U.S. (9 Wheat.) 738 (1824). 
are "tribunals over which the government of the Union has no adequate control, and which may be closed to any claim asserted under a law of the United States." ${ }^{78}$ Federalist Congressman Robert Harper of South Carolina expressed the view in congressional debates about the 1801 judiciary bill-specifically, about the power of Congress to assign cases to state court jurisdiction- "that we cannot enforce on the State courts, as a matter of duty, a performance of the acts we confide to them." ${ }^{79}$ Hamilton made a similar claim in 1802 when, in The Examination, he addressed the prospect of Congress generally using state courts to execute federal law:

In the investigation of our subject, it is not to be forgotten, that the right to employ the agency of the State Courts for executing the laws of the Union, is liable to question, and has, in fact, been seriously questioned. This circumstance renders it the more indispensable, that the permanent organization of the Federal Judiciary should be adapted to the prompt and vigorous execution of those laws. ${ }^{80}$

The upshot of each of these assertions was that a state may have a constitutional interest in refusing to enforce actions arising under federal law, an interest that comported with general jurisdictional principles.

That said, states readily enforced actions in which federal law provided a rule of decision, except federal penal actions (which the next section addresses). Just as states had an interest in enforcing actions arising under the laws of other nations, states had an interest in enforcing actions arising under federal law. State court enforcement of federal law, like state court enforcement of transitory actions generally, worked to the "mutual advantage" and "interests of commerce" of both governments. ${ }^{81}$

Indeed, states arguably had a stronger interest in enforcing federal law actions than they had in enforcing actions arising under the laws of other countries. First, federal law governed in the very territories in which state laws also governed. By exercising jurisdiction, a state could enforce federal law in the way that the state thought federal law ought to be enforced. The more suspicious a state's view of federal authority, the more important it was that a state maintain control over the enforcement of federal law. ${ }^{82}$

78. Id. at 821 .

79. 10 AnNals of Cong. 892 (Joseph Gales ed., 1801).

80. Alexander Hamilton, The Examination No. 6 (Jan. 2, 1802), in 25 The PAPERS of Alexander Hamilton 484, 487-88 (Harold C. Syrett ed., 1977).

81. Jackson v. Rose, 4 Va. (2 Va. Cas.) 34, 36 (1815).

82. The Virginia and Kentucky Resolutions of 1798 and 1799 , for example, which asserted certain powers in states to declare acts of Congress unconstitutional, depended upon state courts having jurisdiction to enforce federal law. See Thomas Jefferson, Kentucky Resolutions of 1798 and 1799 , reprinted in 5 The Founders' ConstruUtion 131, 131-35 (Philip B. Kurland \& Ralph Lerner eds., 1987); James Madison, Virginia Resolutions, reprinted in 5 THE Founders' Constitution, supra, at 135-36. 
Second, by exercising jurisdiction, a state could provide its citizenry with a more convenient forum for the adjudication of actions arising under federal law than a federal forum might be. The convenience of federal courts (or lack thereof) was at issue in pre-ratification debates over whether states should ratify the Constitution and post-ratification debates over how Congress should structure the federal judiciary. Anti-Federalists used the potential inconvenience to litigants that federal jurisdiction would cause as an argument against ratification. Luther Martin observed, for example, that:

Should any question arise between a foreign consul and any of the citizens of the United States, however remote from the seat of empire, it is to be heard before the judiciary of the general government, and in the first instance to be heard in the supreme court, however inconvenient to the parties, and however trifling the subject of dispute. ${ }^{83}$

The Federalist response to such arguments was that Congress would not constitute federal tribunals that were inconvenient to litigants. ${ }^{84}$

Once the Constitution was ratified, the convenience issue remained prominent in debates over how Congress should structure federal court jurisdiction. ${ }^{85}$

83. Luther Martin, Mr. Martin's Information to the General Assembly of the State of Maryland, reprinted in 2 THE Complete ANTI-Federalist 27, 69 (Herbert J. Storing ed., 1981). Similarly, the "Federal Farmer" wrote in 1787 that:

[W]ith all these moving courts, our citizens, from the vast extent of the country must travel very considerable distances from home to find the place where justice is to be administered. I am not for bringing justice so near to individuals as to afford them any temptation to engage in law suits; though I think it one of the greatest benefits in a good government, that each citizen should find a court of justice within a reasonable distance, perhaps, within a day's travel of his home; so that, without great inconveniences and enormous expences, he may have the advantages of his witnesses and jury ....

The Federal Farmer, Letter from the Federal Farmer to the Republican (Oct. 9, 1787), reprinted in 2 The Complete ANTI-Federalist, supra, at 230, 231. Richard Henry Lee, commonly believcd to be the Federal Farmer, wrote in a letter to Edmund Randolph in 1787 that:

[P]ower is unnecessarily given in the second section of the third article, to call people from their own country in all cases of controversy about property between citizens of different states and foreigners, with citizens of the United States, to be tried in a distant court where the congress meets.

Richard Henry Lee, Letter of Richard Henry Lee to Governor Edmund Randolph (Oct. 16, 1787), reprinted in 5 THE COMPLETE ANTI-FEDERALIST, supra, at 112, 115. If Congress did not constitute inferior federal courts in each state, Randolph wrote, "the people will be exposed to endless oppression, and the necessity of submitting in multitudes of cases, to pay unjust demands, rather than follow suitors, through great expense, to far distant tribunals, and to be determined upon there, as it may be, without a jury." Id.

84. See, e.g., A Native of Virginia, Observations upon the Proposed Plan of Federal Government, in 9 The Documentary History of the Ratification of the Constitution 679 (Merrill Jensen et al. eds., 1976) (arguing that there was no reason to think that Congress would not "render the federal jurisdiction convenient to every part of the United States").

85. In congressional debates on the First Judiciary Act, Representative James Jackson stated, "[T]he convenience of the people is, or ought to be, the first principle of every Government; and the people are 
In the 1789 congressional debates over how Congress should structure the federal judiciary, representatives argued against giving federal courts certain jurisdiction on grounds that it would cause inconvenience to the citizenry. South Carolina Representative Aedanus Burke, for example, argued against federal court jurisdiction as follows:

With respect to the time of the court sitting, it might be made at a most inconvenient time of the year, and the place might be at the most distant part of the State, where a man might be dragged three or four hundred miles from his home, and tried by men who know nothing of him, or he of them. ${ }^{86}$

Party Federalists responded in the same way that constitutional Federalists had responded in ratification debates. South Carolina Representative William Smith, for example, responded that "every care will be taken to accommodate these courts to the convenience of the citizens of each State." ${ }^{\prime 87}$

The point is that states had interests in judicially enforcing federal actions even if they had no constitutional duty to enforce them. The view that state courts had a power, but not a duty, to enforce federal law, a power that they routinely would exercise, comported with general jurisdictional principles of the law of nations.

$b$. Interests of the United States. Arguments about state court jurisdiction over actions arising under federal law addressed not only the sovereign interests of states, but the interests of the United States as well. Claims that the United States had a sovereign interest in enforcing actions arising under its own laws easily comported with general law jurisdictional principles. Members of the First Congress generally understood Congress to have authority to give federal courts jurisdiction over Article III cases and controversies, including actions arising under federal law. The text of Article III admits of no other reading. What members of the First Congress generally debated was not whether Congress constitutionally could give federal courts jurisdiction over actions arising under federal law, but whether, as a prudential matter, Congress should give federal courts jurisdiction over actions arising under federal law.

The terms of this debate comported with a basic premise of the law of nations, namely that a sovereign had power to judicially enforce its own laws when it had proper jurisdiction over the parties. As Hamilton explained in The Federalist No. 80, "if it be a just principle that every government ought to possess the means of executing its own provisions by its own authority," federal

entitled to expect it." 1 ANNALS of ConG. 832 (Joseph Gales ed., 1790). South Carolina Representative William Smith described the "only question" with respect to the need for a federal judiciary was "which is the plan best calculated to answer the great object we have in this view, the carrying of the Judicial powers into operation with the least inconvenience to the citizens." Id. at 847.

86. Id. at 843 .

87. Id. at 849 . 
courts "ought to preside" in certain cases governed by federal law. ${ }^{88}$ Several members of the first Congress, in debating matters regarding the structure of the federal judiciary, stressed the need for the federal government to have inferior federal courts to enforce federal law. Massachusetts Representative Fisher Ames remarked that " $[\mathrm{t}] \mathrm{he}$ judicial power is, in fact, highly important to the Government and to the people; to the Government, because by this means its laws are peaceably carried into execution." 89 Along similar lines, his colleague from Massachusetts Theodore Sedgwick rhetorically asked, "Is it not essential that a Government possess within itself the power necessary to carry its laws into execution?"90

Some members of Congress argued that Congress should empower federal courts to hear federal actions, rather than leave them exclusively to state courts, because state judges were not accountable to the United States. ${ }^{91}$ Sedgwick, for instance, posed the following hypothetical to Congress in 1789: "Suppose a State Government was inimical to the Federal Government, and its judges were attached to the same local policy, they might refuse or neglect to attend to the national business; they might be corrupt, and in either case the public might sustain an essential injury." $92 \mathrm{He}$ proceeded to ask the following series of rhetorical questions:

And where would be your redress? Shall we apply to the State Legislatures that patronize them? Can we impeach or have them tried? If we can, how is the trial to be had before a tribunal established by the State? Can we expect in this way to bring them to justice? ${ }^{93}$

"Surely," he responded to his own questions, "no gentleman can suppose we can." ${ }^{.94}$ Ames made a similar point:

88. The Federalist No. 80, at 537 (Alexander Hamilton) (Jacob E. Cooke ed., 1961).

89. 1 AnNals of Cong. 837 (Joseph Gales ed., 1790).

90. Id. at 836. Striking a similar theme, Representative John Vining argued " $[\mathrm{t}] \mathrm{hat}$ the power of making laws, of executing them, and a judicial administration of such laws, is in its nature inseparable and indivisible, if not, "justice might be said to be lame as well as blind among us." Id. at 853 .

91. Though the Constitution set forth provisions for an independent federal judiciary, it did not omit the means to hold judges accountable for misconduct. William Rawle explained in $A$ View of the Constitution of the United States of America:

On the whole, it seems that with the right to new model all the inferior tribunals, and thereby to vacate the commissions of their judges, and with the power to impeach all judges whatever, a sufficient control is retained over the judiciary power for every useful purpose; that it is a branch of government wbich the people have the strongest motives to cherish and support, and that if they value and wish to preserve their Constitution, they ought never to surrender the independence of their judges.

William Rawle, A View of the Constitution of the United States of America 281 (Phila., Philip H. Nicklin 2d ed. 1829).

92. 1 AnNals of Cong. 836 (Joseph Gales ed., 1790).

93. Id.

94. $I d$. 
We might with as great propriety negotiate and assign over our legislative as our judicial power; and it would not be more strange to get the laws made for this body, than after their passage to get them interpreted and executed by those whom we do not appoint, and cannot control. ${ }^{95}$

In response to these arguments, other members of Congress contended that state courts in fact were accountable to the United States for their actions in adjudicating actions arising under federal law. Georgia Representative James Jackson, for example, argued as follows: "It has been said in this debate, that the State Judges would be partial, and that there were no means of dragging them to justice. Shall I peremptorily tell the gentlemen who hold this opinion, that there is a constitutional power in existence to call them to account." 96 That power, he explained, was the Supreme Court's "right to annul these partial adjudications." 97 This 1789 congressional debate of course transpired several years before the Supreme Court resolved in 1816 in Martin v. Hunter's Lessee that it in fact did have constitutional power to review state court judgments. ${ }^{98}$

In any event, all of these arguments rested upon the common premise that Congress had power to give federal courts jurisdiction over actions arising under federal law. The question for debate was generally whether Congress, as a prudential matter, ought to confer this jurisdiction. In other words, all arguments in this debate rested upon the premise that the United States had power to judicially enforce its own laws, "a just principle," as Hamilton described it, that was a basic premise of general law jurisdictional principles.

\section{Arguments Outside the General Law Framework}

While the arguments described above generally comported with general law principles, participants in ratification debates and members of the first Congresses advanced some arguments that departed from them. In each instance, however, such arguments relied on specific constitutional provisions that, as read, operated to override general jurisdictional principles.

First, Hamilton argued in The Federalist that Congress could give federal courts exclusive jurisdiction over all Article III "cases" and "controversies." In The Federalist No. 82, Hamilton read the Constitution to allow state courts to adjudicate "transitory" Article III actions so long as "they were not expressly excluded by the future acts of the national legislature" from doing so. ${ }^{99} \mathrm{He}$ thus read the Constitution to recognize a power in Congress that the law of nations

95. Id. at 838. It was argued in Congress in 1800 that "it was a delicate question how far State Judges were amenable to the United States for a faithful discharge of their duty, inasmuch as, if they violated the laws of the United States, they were not constitutional subjects of impeachment by Congress." 10 ANNALs of Cong. 879 (Joseph Gales ed., 1801).

96. 1 AnNaLs of Cong. 861 (Joseph Gales ed., 1790).

97. Id.

98. 14 U.S. (1 Wheat.) 304, 342 (1816).

99. The Federalist No. 82, supra note 72, at 555. 
did not recognize in sovereigns generally. As explained in Part I.B.2, as a matter of general law, one sovereign could render an action local to its courts only in limited circumstances. Hamilton claimed that Congress could render Article III cases and controversies "local" to federal courts in any circumstance. This claim rested upon powers of Congress that Hamilton read Articles I and III to confer. ${ }^{100}$ In The Federalist No. 80, Hamilton observed that each Article III head of jurisdiction served uniquely federal interests. ${ }^{101}$ In The Federalist No. 81 , he explained that Congress's "power of constituting inferior courts is evidently calculated to obviate the necessity of having recourse to the supreme court, in every case of federal cognizance." ${ }^{102}$ Conversely, he observed that if Congress allowed state courts to adjudicate Article III actions, "there would be a correspondent necessity for leaving the door of appeal as wide as possible."103 In other words, Hamilton understood the power that the Constitution conferred upon Congress to constitute inferior federal tribunals to be a power to constitute them with exclusive jurisdiction over any and all Article III cases and controversies.

Certain members of early Congresses made a second constitutional argument regarding the relationship between congressional power and state court jurisdiction that departed from general jurisdictional principles. Specifically, they argued that federal courts, as a constitutional matter, must have exclusive jurisdiction over all or some heads of Article III jurisdiction. Members of Congress made various forms of this argument. Some argued that Article III requires that federal courts have exclusive jurisdiction over all "cases" and "controversies" that Article III specifies. For example, in 1801, certain members of Congress signed a declaration that deemed it "very doubtful on constitutional grounds whether Congress could delegate [Article III] judicial powers to the State Courts." 104

Other members argued that federal courts must have exclusive jurisdiction over Article III "cases" as opposed to "controversies." Article III "cases" are those "arising under" federal law, those "affecting Ambassadors, other public

I00. Article I of the Constitution gives Congress the power "[t]o constitute Tribunals inferior to the supreme Court," U.S. ConsT. art. I, § 8, and ArticIe III provides that "[t]he judicial Power of the United States, shall be vested in one supreme Court, and in such inferior Courts as the Congress may from time to time ordain and establish." Id. art. III, § I.

I0I. The Federalist No. 80, supra note 88 , at 534-4I.

102. The Federalist No. 8I, at 547 (Alexander Hamilton) (Jacob E. Cooke ed., I961).

103. Id. at 547.

104. I0 Annals of Cong. 879 (Joseph Gales ed., 180I). Similarly, Connecticut Representative Rufus Griswold argued in Congress in 1802 that:

The people ... have declared by their Constitution that the Courts shall exist; they have said that their confidence is not and ought not to be reposed in State Courts for the decision of National causes or causes of a civil nature between citizens of different States; they have left nothing upon this subject for us to do, or to decide, but what relates to the form of organizing the National tribunals.

I1 AnNals of Cong. 770 (Joseph Gales ed., 1802). 
Ministers and Consuls," and those "of admiralty and maritime jurisdiction." 105 South Carolina Federalist Abraham Nott argued in Congress in 1801, for example, that federal courts, as a constitutional matter, must have exclusive jurisdiction over all Article III "cases." The basis for his argument was that Article III extended the federaI judicial power to "all Cases" but merely to "Controversies" (without the "all"). ${ }^{106}$ The "all" implied that federal court jurisdiction over Article IIl "cases" had to be exclusive, whereas state courts could adjudicate Article III "controversies." 107

Still others argued that Article III required that federal courts have exclusive jurisdiction over actions that Congress created de novo. Fisher Ames, for example, argued in Congress in August of 1789 that "actions, the cognizance whereof is created de novo, are exclusively of federal jurisdiction; that no person should act as judges to try them, except such as may be commissioned agreeably to the constitution." ${ }^{108}$ On the one hand, Ames claimed, "[t]he State courts were not supposed to be deprived by the constitution of the jurisdiction that they exercised before, over many cases that may be tried now in the national courts." ${ }^{109}$ On the other hand, Ames continued, where Congress creates a new action, "jurisdiction is made de novo" and a "trust is to be exercised." 110 "The Constitution," he explained, has "provided how this trust should be designated." 111 Specifically, Article III provides that this trust can be exercised "only by persons appointed as judges in the manner" that Article III specifies. ${ }^{112}$

Finally, there were arguments that federal courts must have exclusive jurisdiction over certain individual heads of Article III jurisdiction, such as admiralty cases. Professor Collins has presented extensive evidence of these arguments. ${ }^{113}$ As he explains, the predominant arguments were that Article III meant to divest state courts of jurisdiction over these heads of jurisdiction because they were "de novo" actions or for other reasons. ${ }^{114}$

Each of these arguments defined a relationship between federal power and state courts that differed from the one that general principles of jurisdiction would have recognized as subsisting between independent sovereigns. Under general principles of law, so long as an Article III case or controversy was transitory (or even local to a state), a state could exercise jurisdiction over it.

105. U.S. ConsT. art. III, § 2.

106. Id. (emphasis added).

107. 10 AnNals of Cong. 892 (Joseph Gales ed., 1801).

108. 1 AnNals OF Cong. 839 (Joseph Gales ed., 1790).

109. Id.

110. Id.

111. Id. at 838 .

112. Id.

113. See Collins, supra note 76, at 58-105. Professor Collins also specifically presents evidence of arguments that federal courts had to havc exclusive jurisdiction of penal actions arising under federal law. Id. at 93-96. Such arguments, unlike the ones for exclusivity described in this Part, were consistent with general law principles, as the next Part explains.

114. $l d$. at $59 \mathrm{n} .48,61 \mathrm{n} .51,81-84$. 
Each argument described above that federal courts must have exclusive jurisdiction over all or some Article III cases and controversies relied upon Article III as specifically rendering federal jurisdiction exclusive. The purpose of this section is not to critique the merits of these constitutional arguments; it is merely to show that constitutional arguments that congressional power and state court jurisdiction stood in a different relationship than general principles would have recognized relied on specific constitutional provisions governing the existence and jurisdiction of federal courts.

\section{B. FEDERAL PENAL ACTIONS}

This section specially addresses the most notable kind of Article III case over which public officials, during the Founding period and subsequent few decades, argued that federal courts must have exclusive jurisdiction: federal penal actions. This kind of action deserves its own treatment for two reasons. First, the historical record regarding the enforceability of this kind of action in state court is extensive. Second, as this section explains, most officials who argued in favor of exclusive federal jurisdiction of federal penal actions relied not on any specific command of Article III, but on general principles of law. ${ }^{15}$ Accordingly, the historical record surrounding the question whether federal penal actions were enforceable in state courts shows that many public officials understood general law jurisdictional principles to define the relationship between federal power and state court jurisdiction, absent a specific constitutional provision overriding them.

State court jurisdiction of federal crimes was a matter of controversy at the Federal Convention of 1787 and in ratification debates that followed. Postratification, members of Congress debated whether Congress could require or even allow state courts to hear federal criminal actions. The Judiciary Act of 1789 provided that the district courts of the United States would have exclusive jurisdiction of crimes and offenses against the United States "committed within their respective districts, or upon the high seas." 116 It also granted circuit courts concurrent jurisdiction over such offenses and exclusive jurisdiction over all other federal crimes. ${ }^{117}$ In subsequent years, Congress allowed state court jurisdiction over particular federal penal actions. In an influential article published in 1925, Charles Warren chronicled these jurisdictional allowances. ${ }^{118}$

Notwithstanding these allowances, state court jurisdiction of federal penal

115. One exception is Fisher Ames, who would have defined federal penal actions as de novo, and thus a kind of case that he believed Article III required federal courts to hear exclusively. See 1 ANNALS of Cong. 839 (Joseph Gales ed., 1790).

116. Section 9 of the Judiciary Act of 1789,1 Stat. 73 , provided "[ $t]$ hat the district courts shall have, exclusively of the courts of the several States, cognizance of all crimes and offences that shall be cognizable under the authority of the United States, committed within their respective districts, or upon the high seas." Judiciary Act of $1789, \S 9$, ch. 20, 1 Stat. 73, 76-77.

117. Id. $\$ 11,1$ Stat. at 83 .

I18. See WARREN, supra note 71. 
actions remained controversial. Chancellor James Kent asserted in his Commentaries on American Law that federal jurisdiction over "all criminal cases" is "necessarily exclusive." 119 Defendants challenged the constitutionality of state court jurisdiction of federal penal actions in, naturally, state courts. State courts assessed the constitutionality of several provisions that Warren examined, including an 1825 Act of Congress imposing a fine and imprisonment for stealing from the mails ${ }^{120}$ and a penalty for the unauthorized conveyance of letters; ${ }^{121}$ an 1813 Act of Congress imposing a penalty for selling liquor or foreign merchandise without a license; ${ }^{122}$ and an 1830 Act of Congress imposing a penalty for refusing to provide federal census information. ${ }^{123}$ In assessing the constitutionality of these statutes, state courts proceeded from two shared premises: first, that state courts constitutionally could enforce nonpenal federal actions, as such actions fell within the general jurisdiction that they possessed before the Constitution was adopted; $;{ }^{124}$ and second, that under the law of nations, the courts of one sovereign did not enforce the penal laws of another. ${ }^{125}$ What state courts had to decide was whether Congress constitutionally could allow or require state courts to hear federal penal actions. Some state courts held that

119. James Kent, Commentaries on American Law 370-71 (Da Capo Press, 1971) (1826).

120. Act of March 3, 1825, ch. 64, § 22, 4 Stat. 102 (considered in State v. Wells, 20 S.C.L. (2 Hill) 687 (Ct. App. 1835); State v. McBride, 24 S.C.L. (Rice) 400 (Ct. Err. 1839)).

121. Act of March 3, 1825, ch. 64, $\S 19,4$ Stat. 102 (considered in Davison v. Champlin, 7 Conn. $244,246(1828))$.

122. Act of Aug. 2, 1813, ch. 39, $\S 1-2,5,3$ Stat. 72 (considered in United States v. Lathrop, 17 Johns. 4, 4 (N.Y. 1819); Hartley v. United States, 4 Tenn. 45, 45 (1816); Jackson v. Rose, 4 Va. (2 Va. Cas.) 34,35 (1815)).

123. Act of March 23, 1830, ch. 40, $\$ 6,4$ Stat. 383 (considered in Haney v. Sharp, 31 Ky. (1 Dana) 442 (1833)).

124. See Davison, 7 Conn. at 250 (stating that "there is a broad distinction between suits on bonds given to the United States, suits for seamen's wages, \&c. \&c. where the courts of the state have a common law jurisdiction, and actions for penalties for the violation of the penal laws of the United States"); Lathrop, 17 Johns. at 8 (stating that the Constitution "does not necessarily divest the state courts of jurisdiction in all those cases to which their jurisdiction extended, before the adoption of the constitution"); Wells, 20 S.C.L. at 691 (circuit court opinion of Earle, J.) (stating "jurisdiction in all such cases arises from the original and inherent structure of the State governments, having cognizance, necessarily, of cases under their own laws, anterior to the Constitution of the United States, and independent of it, where those laws are not incompatible with those of the general government"), rev'd 20 S.C.L. 694, 698 (Ct. App. 1835); Hartley, 4 Tenn. at 49 (stating that "the State tribunals will continue the jurisdiction which they had before the formation of the Constitution").

125. See Davison, 7 Conn. at 248-49 (stating that it "is the acknowledged law, that the courts of one state cannot enforce the penal laws of another state"); Lathrop, 17 Johns. at 9 (stating that "it is a fundamental maxim, that the courts of one sovereignty will not take cognizance of nor enforce the penal code of another"); id. at 21 (Platt, J., dissenting) (stating that "[i]n regard to the distinction between civil actions founded on penal statutes, and actions on contracts, the law and usage of nations impose no obligation on one sovereign to afford a remedy to enforce a penal law of another sovereign;"); McBride, 24 S.C.L. at 413 (stating that "[i]t is . . a settled principle of jurisprudence, sanctioned by the practice of all countries, especially of England and of these States, that the courts of one country will not enforce the penal laws of another, much less will they undertake to prosecute and punish crimes and pubhic offenses against another"). 
Congress could allow or require such jurisdiction; ${ }^{126}$ others held that Congress could do neither. ${ }^{127}$ While the Supreme Court did not expressly decide this question in the nineteenth century, several justices endorsed the view that Congress constitutionally could not give state courts jurisdiction of federal penal actions. In 1816, Justice Joseph Story wrote in Martin v. Hunter's Lessee ${ }^{128}$ that "[n]o part of the criminal jurisdiction of the United States can, consistently with the constitution, be delegated to state tribunals." ${ }^{29}$ In his 1820 dissenting opinion in Houston v. Moore, ${ }^{130}$ Justice Story cbaracterized Martin as "expressly" holding "that no part of the criminal jurisdiction of the United States can consistently with the constitution be delegated by Congress to State tribunals ...." ${ }^{131}$ In 1835, in a dissenting opinion in United States v. Bailey, ${ }^{132}$ Justice John McLean asserted that "the judiciary of a state" cannot "carry into effect the criminal laws of the union."133

In his influential 1925 article, Charles Warren explained that "trial in the State Courts of ... violations of Federal criminal law was regarded by Congress as natural, feasible, and desirable" 134 and concluded that the "doctrine that no Court could enforce the penal laws of another Government seems to have been established as a judicial pronunciamento, without much reasoning, and chiefly from the desire of the Federal Courts to avoid friction with the States at a

126. See, e.g., Wells, 20 S.C.L. at 697 ("A violation of statute law which is made criminal, but for the punishment of which no particular forum is selected, may be punished by any Court where the law is obligatory, which has a general criminal jurisdiction, and which also has local jurisdiction of the act done, and of the person of the offender."); see also, e.g., Hartley, 4 Tenn. at 51 ("If a case is brought before [state judges] in which a right is claimed to recover by virtue of [a federal] law, the court is in duty bound to hear and determine it, unless it be a case where the jurisdiction is exclusively vested in the United States' tribunal.").

I27. See, e.g., Davison, 7 Conn. at 248 ("Congress have no power to give a state court jurisdiction over cases of a penal or criminal nature arising under the laws of the United States."); Lathrop, 17 Johns. at 10 ("[T]his court has no jurisdiction of the criminal offences or penal laws of the U.S.; and that it is not competent to Congress to confer jurisdiction ...."); Jackson, 4 Va. (2 Va. Cas.) at 41 ("It is the unanimous opinion of this Court, that to assume jurisdiction over this case, would be to exercise a portion of the Judicial power of the United States, which by the Constitution is clearly and distinctly deposited in other hands ....").

I28. I4 U.S. (I Wheat.) 304 (1816).

I29. Id. at 337.

130. 18 U.S. (5 Wheat.) 1 (1820).

131. Id. at 69 (Story, J., dissenting). The Supreme Court, however, has considered Martin's language in this regard to be mere dicta. See Testa v. Katt, 330 U.S. 386, 390, 391 n.6 (1947) (citing Martin in support of the proposition that the Court has merely "questioned the power and duty of state courts to exercise their jurisdiction to enforce Unted States civil and penal statutes or the power of the Federal Government to require them to do so").

132. 34 U.S. (9 Pet.) 238 (1835).

133. Id. at 259 (McLean, J., dissenting). Justice McLean expressed the same sentiment in a dissenting opinion in 1847 in Fox v. Ohio, 46 U.S. (5 How.) 410, 438 (1847) (McLean, J., dissenting) ("It is therefore clear, that the same power cannot be exercised by a State court as is exercised by the Courts of the United States, in giving effect to their criminal laws.").

134. Warren, supra note 71, at 545. The Supreme Court cited this work in the landmark case of Testa v. Katt, 330 U.S. 386,390 n.5, 391 n.6 (1947). 
particularly nervous period." 135 The historical record is more complicated than this conclusion suggests. The doctrine that no court could enforce the penal laws of another government was not "established as judicial pronunciamento," 136 but rather was a well-recognized jurisdictional principle of the law of nations. Arguments that this doctrine constitutionally limited the power of Congress to allow or require state courts to hear federal penal actions began before ratification and persisted for decades. Constitutional arguments about the power of Congress to allow or require state courts to hear federal penal actions that did not rely on this doctrine instead relied upon specific constitutional provisions that, as read, operated to override general jurisdictional principles. It was not the case, as Warren argued, that the Constitution was generally understood to contemplate state court jurisdiction of federal penal actions with a few judges pronouncing a novel doctrine to keep federal penal actions out of state courts. Rather, the historical record demonstrates that public officials widely understood the law of nations to define the relationship between Congress and state courts unless the Constitution specifically altered some aspect of that relationship.

This section explains how delegates to the Federal Convention, participants in ratification debates, legislators, judges, and treatise-writers made arguments regarding state court jurisdiction of federal penal actions either within the framework of general principles of jurisdiction or on the basis of specific constitutional provisions read to alter the balance of power between Congress and state courts that the law of nations otherwise would have recognized.

\section{Arguments Within the General Law Framework}

Many arguments about state court jurisdiction over federal penal actions recognized the same sovereignty interests of individual states and the United States that the law of nations recognized with respect to interjurisdictional enforcenient of penal actions generally.

a. Interests of the Forum State. Some public officials argued that Congress could not require state courts to hear federal penal actions because states had a sovereign interest in not enforcing federal penal laws. Certain officials argued in particular that federal penal laws simply were of no concern to states. South Carolina Federalist Abraham Nott argued in the House of Representatives in 1801 , regarding a proposed amendment that would leave jurisdiction of certain federal penal actions in state courts, as follows:

It was essential in every indictment, to lay the offence to have been committed against the law of the State, and to conclude against the peace and dignity of the same. But, surely, gentlemen would not contend that an offence against

135. Warren, supra note 71 , at 584.

136. Id. 
a law of the United States was an offence against the law of an individual State, or against its peace and dignity. ${ }^{137}$

Certain state courts analyzing whether they had to enforce penal laws of the United States argued that federal penal policy might be incompatible with state penal policy or that the judicial procedures that federal penal laws required might be offensive to the dignity of the state. In Jackson v. Rose, the General Court of Virginia, refusing to enforce a federal penal statute, explained that "there is no good reason why one Nation should authorise its Judiciary to carry the Penal Laws of another into execution ...." 138 Among other reasons, the court explained, state enforcement of such laws would introduce the same kind of "Mosaik work into the Judiciary system" that the enforcement of one nation's penal laws by another would introduce-for example, "The Judges of Republican Virginia pillorying an Englishnian for libelling Royalty, and the Court of King's Bench inflicting the same punishment upon an American for libelling the Government of the United States for the late declaration of war." ${ }^{139}$ In State v. Wells, South Carolina courts considered a federal penal statute requiring them to apply certain federally specified procedures. Justice Baylis Earle observed that "[b]y our laws, in cases of misdemeanor, the defendant is entitled to an imparlance. By the act in question, the Court is required to hear and determine the cause at the first Court."140 Justice Earle contended that a state court's enforcement of federal penal laws according to federal procedures "would invest it with a mongrel character wholly irreconcilable with its dignity and that of the State from which it derives its appointment."141

These arguments addressed, in today's terms, the "anticommandeering" aspects of this problem. In Jackson v. Rose, Virginia's highest court, in holding that Congress may not require state courts to enforce federal penal laws, explained "that the Judiciary of one separate and distinct Sovereignty cannot of itself assume, nor can another separate and distinct Sovereignty either authorise, or coerce it to exercise the Judicial powers of such other separate and distinct Sovereignty."142

b. Interests of the United States. Some public officials argued that Congress could not allow state courts to hear federal penal actions because, as a matter of general law, the United States had sovereignty interests in exclusively enforcing its own penal laws. Different officials made different points in this regard, but each point corresponded to reasons that courts and treatise writers provided to

137. 10 AnNals of Cong. 895-96 (Joseph Gales ed., 1801).

138. Jackson v. Rose, 4 Va. (2 Va. Cas.) 34,36 (1815).

139. Id. at 36-37.

140. State v. Wells, 20 S.C.L. (2 Hill) 687, 693 (Ct. App. 1835) (circuit court opinion of Earle, J.), rev'd, 20 S.C.L. (2 Hill) 694 (Ct. App. 1835).

141. $I d$.

142. Jackson, 4 Va. (2 Va. Cas.) at 35 (emphasis added). 
justify the penal law exception in the law of nations: first, that state court enforcement might frustrate federal penal policy; second, that state court enforcement would generate anomalies regarding the sovereign to which penalties were owed; and third, that state court enforcement would generate irreconcilable conflicts regarding the operation of state and federal pardon powers.

The first point was that state court enforcement of federal penal laws could frustrate federal penal policy. In 1789, in debates over the first judiciary bill, South Carolina Representative William Smith argued that "[i]t is very proper that a court in the United States should try offences committed against the United States. Every nation upon earth punishes by its own courts offences against its own laws." ${ }^{143}$ Regarding state court adjudication of offenses against the United States, Smith argued, "[ $[$ ]he disinclination of the judges to carry the law into effect, their disapprobation of a certain duty, the rules of the court, or other obvious causes," could operate to frustrate federal policy. ${ }^{144}$ Connecticut Representative Rufus Griswold struck a similar chord in congressional debates over the 1802 judicial reorganization bill, noting "[ $[$ ] State justice for the execution of our penal laws ...."145 He deemed it "a gross evasion of the Constitution to leave the organization of [inferior federal] courts materially defective." 146

A related concern was that state courts were unaccountable to the United States for how they enforced federal penal laws. In Jackson $v$. Rose, the Virginia court explained:

So great an absurdity cannot be supposed, as that the Constitution intended to put the Judicial power of the United States into the hands of Judges, in no way responsible to its Government. Yet no man can pretend that the State Judges can be impeached, and tried by that Government. ${ }^{147}$

Indeed, at least two state courts suggested that, because one nation did not enforce the penal laws of another, state courts would be acting as unlawfully constituted federal courts if they enforced federal penal laws. In Davison $v$.

143. 1 ANNALS OF Cong. 830 (Joseph Gales ed., 1790).

144. Id. In his Lectures on Law, James Wilson provided reasons why criminal policy depended not only on how crimes were defined but on how the criminal law was executed:

The certainty of punishments is of the greatest importance, in order to constitute them fit preventives of crimes. This certainty is best obtained by accuracy in the public police, by vigilance and activity in the executive officers of justice, by a prompt and certain communication of intelligence, by a proper distribution of rewards for the discovery and apprehension of criminals, and, when they are apprehended, by an undeviating and inflexible strictness in carrying the laws against them into sure and full execution.

James Wilson, Lectures on Law, in 2 THE Works of JAMES WILSON 68 (James DeWitt Andrews ed., 1896).

145. 11 ANNALS OF Cong. 770 (Joseph Gales ed., 1802).

146. $I d$.

147. Jackson, 4 Va. (2 Va. Cas.) at 40. 
Champlin, the Supreme Court of Errors of Connecticut held that state judges cannot enforce federal penal actions because state courts "are appointed, the tenure of office fixed, and compensation and responsibility regulated, by the constitution and laws of the states." 148 In State v. McBride, South Carolina's highest court asked rhetorically: "How then can congress constitute inferior tribunals, by distributing its judicial power among twenty-six judiciaries of the States, appointed by the States, paid by the States, and holding their office by every variety of tenure?"149 The understanding of these courts appears to have been that, unless a state court had jurisdiction over a federal law action under general jurisdictional principles-that is, a state court could enforce a federal action as a state court-a state court could not enforce a federal action.

The second point that public officials made regarding the interests of the United States in exclusively enforcing its own penal laws was that state court enforcement of federal penal laws would generate anomalies regarding the sovereign to which penalties were owed. In 1828, the Supreme Court of Errors of Connecticut identified "difficulties easily suggested to a reflecting mind" if state courts constitutionally could enforce federal penal actions: "To what treasuries are the forfeitures to belong? What gaols are to receive those who are to be imprisoned? To what tribunals are sheriffs amenable for neglect or violation of duty?"150 In 1835, in State v. Wells, Justice Earle raised the following questions regarding state court enforcement of federal penal laws: "By our laws, fines and forfeitures are appropriated to a special purpose. Could this penalty, incurred by a violation of an act of Congress, be so appropriated? or be diverted at all from the channel provided by the laws of the United States?"151 Justice Earle concluded that state court enforcement of federal penal actions, as with one nation's enforcement of another's penal laws, "would present a succession of conflicting powers and authority, easier to be imagined than to be described or obviated." 152

The third point that public officials made regarding the interests of the United

148. Davison v. Champlin, 7 Conn. 244, 248 (1828).

I49. State v. McBride, 24 S.C.L. (Rice) 400, 41 I (Ct. Err. 1839); see also United States v. Lathrop, I7 Johns. 4, 7 (N.Y. 18I9) (stating that federal dependence "on the judiciary of the several states, over whom the United States had no control, for the exposition or execution of the laws of the United States... would have been incompatible with the stability or permanency of the government itself'). Michael Collins has described the nature of arguments in the First Congress that if Congress gave state courts jurisdiction of Article III business that had to be exclusively vested in Article III courts, state courts could become federal courts. Michael Collins, The Federal Courts, the First Congress, and the Non-Settlement of 1789, 91 VA. L. Rev. 1515, 1548-52 (2005).

150. Davison, 7 Conn. at 249.

151. State v. Wells, 20 S.C.L. (2 Hill) 687, 693 (Ct. App. I835) (circuit court opinion of Earle, J.).

152. 1d. Earle also questioned whether, if a state court consented to hear a federal penal action, the state executive would have any obligation to execute the judgment. He knew "no authority" by which a court "could compel the jury to try it or the sheriff to carry the sentence into execution. I make bold to say, in such case, if the jury should refuse to try the cause, or the sheriff to aid in carrying the sentence into execution, the court dare not lay a finger on either, by way of contempt." McBride, 24 S.C.L. at 405 . 
States in exclusively enforcing federal penal laws was that state court enforcement of federal penal laws would generate unsolvable problems regarding which sovereign held the pardon power. As explained, some courts and treatise writers justified the penal law exception in the law of nations on the ground that the pardon power only resided in the state under the laws of which a crime arose. Because the pardon power could not extend extra-territorially, for one state to prosecute a crime against another would effectively deprive the other state of its pardon power and render a crime unpardonable. ${ }^{153}$

The Supreme Court has long understood the President's pardon power with reference to the pardon authority of the English crown at the time of the Founding. ${ }^{154}$ Delegates to the Federal Convention of 1787 and participants in ratification debates were familiar with the pardon power as it existed under Enghish law. ${ }^{155}$ Under English law, the pardon power was an inseparable, indivisible, and indefeasible incident of crown authority. ${ }^{156}$ Prominent expositors of the Constitution, such as Alexander Hamilton and Joseph Story, understood the federal pardon power in America to be a similar incident of presidential

153. See supra notes $63-64$ and accompanying text.

154. See Ex parte Grossman, 267 U.S. 87, $108-09$ (1925) ("The language of the Constitution cannot be interpreted safely except by reference to the common law and to British institutions as they were when the instrument was framed and adopted."); Ex parte Wells, 59 U.S. (18 How.) 307, 311 (1855) ("[W] hen the words to grant pardons were used in the constitution, they conveyed to the mind the authority as exercised by the English crown, or by its representatives in the colomies."); United States v. Wilson, 32 U.S. (7 Pet.) 150, 160 (1833) ("As this power [of pardon] had been exercised from time immemorial by the executive of that nation whose language is our language, and to whose judicial institutions ours bear a close resemblance, we adopt their principles respecting the operation and effect of a pardon.").

155. See W.H. Humbert, The Pardoning Power of the President 14-20 (1941) (describing consideration of the executive pardon power at the Federal Convention and in ratification debates); William F. Duker, The President's Power To Pardon: A Constitutional History, 18 WM. \& MARY L. Rev. 475, 501-06 (1977) (same); see also Christen Jensen, The Pardoning Power in the American States 4 (1922) (describing how in most colonial charters the king delegated the pardon power and provided for its exercise).

156. See Groenvelt's Case, (1697) 91 Eng. Rep. 1038, 1038 (K.B.) (Holt, C.J.) ("[T]he King neither by grant nor otherwise can pass his power, or extinguish that power which he hath to pardon offenses. For ... it is a personal trust and prerogative in him, for a fountain of grace and bounty to his subjects, as he observes them deserving or useful to the public."); The King v. Parsons, (1692) 89 Eng. Rep. 575 (K.B.) (Holt, C.J.) ("The power of pardoning all offenses is an inseparable incident to the Crown and its Royal power. It is as much for the good of the people, that the King should pardon, as that he should pumish."); 5 Matthew Bacon, A New Abridgement of the Law 285 (London, A. Straham 1807) ("The power of pardoning offences is inseparably incident to the crown . . ."); 4 BlACKSTONE, supra note 29, at $* 390$ (" $[N]$ o other person hath power to pardon or remit any treason or felonies whatsoever; but that the king hath the whole and sole power thereof, united and knit to the imperial crown of this realm."); John Brydall, A New-Years-Gift for the Anti-Prerogative Men: or, A Lawyers Opinion, in Defence of his Majesties Power-Royal, of Granting Pardons, as he Pleases 7 (1682) ("[C]ertainly we may conclude that he who has Vested in him the Sovereign Power, has also Vitae ac necis Authoritatem, the sole power of Life and Death, to save or destroy, as well to pardon as to punish Offenders."); 1 JOSEPH Chitty, A Practical Treatise on the Criminal Law 761 (1836) ("The prerogative of pardoning is inseparably incident to the crown, in which it is vested for the benefit of the subject."). 
authority. ${ }^{157}$ Both the Crown and the President could exercise the pardon power for a range of reasons, including the defendant's innocence, the disproportionality of the punishment imposed, the unfaimess of the trial, the injustice of the conditions of the defendant's confinement, or the defendant's rehabilitation. ${ }^{158}$ In England and America, writers commonly explained the pardon power as exercisable in the interests of justice or mercy. ${ }^{159}$ In light of the general law, the executive who exercised the pardon power for any of these reasons was understood to be the executive of the sovereign that both created the criminal liability and enforced it.

The notion of state courts enforcing federal criminal law generated the question of who would hold the pardon power: the President (on behalf of the sovereign creating criminal law), the state executive (on behalf of the sovereign

157. See The Federalist No. 74, at 501 (Alexander Hamilton) (Jacob E. Cooke ed., 1961) ("As the sense of responsibility is always strongest, in proportion as it is undivided, it may be inferred that a single man would be most ready to attend to the force of those motives which might plead for a mitigation of the rigor of the law ...."); JOSEPH STORY, COMMENTARIES ON THE CONSTTTUTION OF THE UNITED STATES 551 (1833) ("A single magistrate would be compelled to search, and act upon his own responsibility; and, therefore, would be at once a more enlightened dispenser of mercy, and a more firm administrator of public justice.").

158. See HUMBerT, supra note 155, at 17-20 (analyzing reasons for exercises of presidential pardon power); Peter King, Crime, Justice, and Discretion in England 1740-1820, at 297-333 (2000) (providing empirical analysis of the reasons for pardon requests and grants in England from 1787-90).

159. For examples of English writings, see 5 BACON, supra note 156, at 285 ("[T]his high prerogative the king is intrusted with upon a special confidence, that he will spare those only whose case, could it be foreseen, the law itself may be presumed willing to have excepted out of its general rules, which the wisdom of man cannot possibly make so perfect as to suit every particular case."); 4 BLACKSTONE, supra note 29 , at $* 390$ ("This is indeed one of the great advantages of monarchy in general, above any other form of government; that there is a magistrate, who has it in his power to extend mercy, wherever he thinks it is deserved ...."); 1 CHITTY, supra note 156, at 770 ("But it must be admitted that there are many cases to which no general rules can apply; where 'summum jus' would be 'summa injuria;' and where forgiveness is, at once, beneficial to the crown which bestows, and just to the party who receives it."); 5 Comyss, supra note 29 , at 171 ("The king by his prerogative, may grant his pardon to all offenders attainted or convicted of a crime, where he has hope of their amendment."); 17 Charles Viner, A GeNeral ABRidGement of Law AND EquTtY 18 (2d ed. 1791) ("[A] general pardon shall be taken more for the benefit of the party, because this proceeds from the king himself, and of his special grace ...."); The Prerogative of Pardon and the Punishment of Death, 81 WestMINSTER REv. 185, 186 (Am. ed. 1864) ("The most tenable form in which the defenders of the prerogative can put their case is this: human laws are imperfect, and it is therefore necessary to provide some means by which in individual instances their sentences may be reversed when erroneous, commuted when unduly severe, and remitted when their execution would be injurious to the interests of the community.").

For examples of American writings, see THe Federalist No. 74, supra note 157, at 507 ("The criminal code of every country partakes so much of necessary severity, that without an easy access to exceptions in favor of unfortunate guilt, justice would wear a countenance too sanguinary and cruel."); KENT, supra note 119, at 283 ("[P]olicy ... sonetimes require[s] a remission of a punishment strictly due, for a crime certainly ascertained."); STORY, supra note 157, at 366 ("The criminal code of every country partakes so much of necessary severity, that without an easy access to exceptions in favor of unfortunate guilt, justice would assume an aspect too sanguinary and cruel."); James Wilson, Lectures on Law, in 2 THE Works of JAMES WILSON 71 (James DeWitt Andrews ed., 1896) ("In the mildest systems, of which human societies are capable, there will still exist a necessity of this discretionary power, the proper exercise of which may arise from the possible circumstances of every conviction."). 
enforcing the criminal law), or both. James Madison's notes from the Federal Convention reveal that he was concerned that if state courts were to enforce federal penal laws, the Constitution had to be ratified in such a way as to divest state executives of power to pardon federal offences tried in state courts. The plan that William Paterson laid before the Convention-the so-called New Jersey Plan-called for state courts to adjudicate federal actions, including penal actions, subject to appellate review in a federal court. ${ }^{160}$ Madison expressed concern about how this provision would affect the pardoning power of state executives. Specifically, the New Jersey Plan called for ratification by state legislatures; Madison questioned whether state legislatures, by ratifying a federal constitution, could take away the pardoning power of state executives. ${ }^{161}$ Madison's question implied, first, that the power of pardoning crimes arising under federal law would reside in the federal government; and, second, that this power should preclude state executives from having power to pardon federal crimes that state courts adjudicated. In other words, Madison suggested that if the Constitution were to place jurisdiction of federal crimes in state courts, it had to be ratified in such a way as to legitimately divest state executives of the power to pardon federal crimes prosecuted in state courts. ${ }^{162}$

Judges who later addressed the enforceability of federal penal laws in state courts did not presume that the Constitution divested state executives of the power to pardon offenders convicted of federal crimes in state courts. In 1820, in Houston v. Moore, ${ }^{163}$ the Supreme Court had to resolve whether a state constitutionally could punish in its own courts an offense that Congress had made an offense against the United States. Houston, whom a state court martial had tried for such an offense, argued that a state court martial could not try a defendant for a federal criminal offense because "the Governor of that State, in

160. Specifically, Paterson's Plan (as recorded by Madison) provided:

[T]hat all punishments, fines, forfeitures \& penalties to be incurred for contravening such acts rules and regulations shall be adjudged by the Common law Judiciarys of the State in which any offence contrary to the true intent \& meaning of such Acts rules \& regulations shall have been committed or perpetrated, with liberty of commencing in the first instance all suits \& prosecutions for that purpose in the superior Common law Judiciary in such State, subject nevertheless, for the correction of all errors, both in law \& fact in rendering judgment, to an appeal to the Judiciary of the U. States.

1 Records of the Federal Convention 243 (Max Farrand ed., rev. ed. 1966).

161. Madison wrote with respect to this provision of Patterson's plan: "[I]n most if not all of the States, the Executives have by their respective Constitutions the right of pardg. How could this be taken away from them by a legislative ratification only?" Id. at 317.

162. Madison also raised a question in his notes on the Federal Convention implicating double jeopardy concerns with respect to state court enforcement of federal penal laws. Paterson's "New Jersey Plan," as explained, provided for the prosecution of federal crimes in state courts, subject to review in a federal appellate tribunal. Madison observed in his notes that "[t]he necessity of any such provision supposed a danger of undue acquittals in the State tribunals." Id. He proceeded to question, however, "[o]f what avail an appellate tribunal [would] be, after the acquittal." Id. The implication is that a federal appellate tribunal would be of no avail because reversing an acquittal would place the defendant in double jeopardy.

163. 18 U.S. (5 Wheat.) l (1820). 
case of conviction, might have pardoned them."164 Justice Bushrod Washington, in an opinion announcing the judgment of the Court but speaking only for himself, took no position on the question whether a governor could pardon a federal offense tried in a state court. He simply took the view that a state executive power to pardon federal crimes was not a constitutional barrier to state courts trying federal offenses. In Justice Washington's view, a state executive power to pardon federal offenses tried in state courts "would only furnish a reason why Congress should vest the jurisdiction in these cases, exclusively [in federal courts]." 165

Some state judges, however, viewed the pardon puzzle as one of constitutional proportions. South Carolina Justice Baylis Earle argued that state court enforcement of federal penal laws was unconstitutional because, among other reasons, it would create an unsolvable puzzle regarding who held the pardon power-the governor of the state or the President of the United States. As Earle put the matter: "By the Constitution of the State, the Executive has the power of pardon in all cases of conviction in our own courts. Could the defendant plead the Governor's pardon in bar of the sentence? or should he appeal to the clemency of the President?"166 Such difficulties led Earle to conclude that, as a constitutional matter, federal courts must have exclusive jurisdiction of federal penal actions. Along similar lines, in 1872 in United States ex rel. Hendricks $v$. Harris, ${ }^{167}$ a federal district court explained: "[S]tate courts cannot hold jurisdiction over offenses exclusively existing as offenses against the United States. Every criminal presentation must charge the offense as having been committed against the sovereign whose courts sit in judgment on the offender, and whose executive may pardon him." ${ }^{168}$ Each of these judges expressed general-lawrelated concerns to argue against state court enforcement of federal penal laws.

Contrary to general-law-based arguments that state courts could not constitutionally enforce federal penal laws, one state judge invoked general jurisdictional principles to argue in favor of the constitutionality of state court enforcement of federal penal laws. In 1819, New York State Supreme Court Justice Jonas Platt argued in dissent in United States v. Lathrop ${ }^{169}$ that the import of the general law was not that one state never could judicially enforce another's penal laws but that a state could not judicially enforce another's penal

I64. Id. at 31 .

165. Id.; see also KENT, supra note 119, at 373-74 (1830) (describing the possibility of state executive power to pardon a federal offense as a "difficulty, not so easily surmounted" as others in Houston v. Moore).

166. State v. Wells, 20 S.C.L. (2 Hill) 687, 69I (Ct. App. 1835) (opinion of Earle, J.).

167. 26 F. Cas. I77 (C.C.D.S.C. 1872) (No. 15,3I3).

168. Id. at 183; see also Brown v. United States, 4 F. Cas. 98, 100-01 (C.C.N.D. Ga. 1875) (No. I,862) (" $[T]$ he state courts cannot hold criminal jurisdiction over offences exclusively existing as offences against the United States; for every criminal prosecution must charge the crime to have been committed against the sovereign whose courts sit in judgment upon the offender, and whose authority can pardon him.").

I69. 17 Johns. 4 (N.Y. 18I9). 
laws without the other's consent. ${ }^{170}$ Justice Platt explained:

It is said to be a fundamental maxim, that the courts of one sovereign will not take cogmizance of, or enforce, the penal laws of another sovereign; but I think it more correct to say, that one sovereign ought not to entrust the execution of his penal laws to the courts of another sovereign. ${ }^{171}$

Thus, he argued, though it might be "inexpedient and unwise" for Congress to allow state court jurisdiction of federal penal laws, there was "no ground to say that such an act would be unconstitutional."172 That said, Platt saw reasons why, unlike in the case of sovereigns entirely foreign to each other, Congress might choose to entrust enforcement of federal penal laws to state courts. First, "the appellate power of the Federal Courts attaches in all those cases" arising under federal law that state courts adjudicate. ${ }^{173}$ Thus, Supreme Court review would be "ordinarily an ample remedy for correcting state influence or partialities, and producing uniformity of decision." 174 Moreover, he explained, Congress always has "a discretion to make the jurisdiction of the Federal Courts . . . exclusive or concurrent." 175 On this basis, "when we consider the complex and peculiar structure and relations of our federal government and our state governments," Platt concluded, "the practice of other independent nations affords no analogy sufficiently strong to guide us in the present case." a practice did not entrust the execution of their penal laws to other nations did not mean that, as a matter of general law, they understood themselves to be prohibited from doing so.

\section{Arguments Outside the General Law Framework}

Most arguments in favor of state court jurisdiction of federal penal actions relied on a specific constitutional provision alleged to override general law principles in this context, namely the Supremacy Clause. ${ }^{177}$ In State v. Wells, the

170. Id. at 8 (Platt, J., dissenting). For differing views on the import of the law of nations in this regard, compare 5 St. George Tucker, Blackstone's Commentaries: with Notes of Reference to the Constitution and Laws of the Federal Government of the United States and the Commonwealth of VIRGINIA app. 3-10 (Philadelphia, William Young Birch \& Abraham Small 1803) ("The cognizance of all crimes and misdemeanors committed within the body of any state, therefore, belongs exclusively to the jurisdiction of that state; unless it hath by compact or treaty surrendered its jurisdiction in any particular cases to some other power."), with WILliam Rawle, A VIEW OF THE CONSTITUTION of THE UNTED States 189 (Philadelphia, H.C. Carey \& I. Lea 1825) ("[T]he United States may, whenever it is found expedient, elect to make use of a state tribunal to the same extent as any foreign power may, if it thinks proper to institute suits in the courts of other countries, which is in civil cases only.").

171. United States v. Lathrop, 17 Johns. 4, 21-22 (N.Y. 1819) (Platt, J., dissenting).

172. Id. at 21 (Platt, J., dissenting) (empbasis added).

173. Id. at 15 (emphasis added).

174. Id.

175. Id. at 14 .

176. Id. at 22 (emphasis added).

177. See U.S. ConST. art. VI, cl. 2. 
South Carolina Court of Appeals, reversing Justice Earle's Circuit Court opinion, held that state courts can and must enforce federal penal laws because "[t]he constitutional legislation of the United States is the command of South Carolina as well as of the United States." 178 Federal law, the South Carolina court explained, binds "the officers and people" of South Carolina "and more especially the judges, for the Constitution declares that they 'shall be bound thereby, any thing in the Constitution or laws of any State to the contrary notwithstanding." "179 In 1816, Justice John Haywood of the Supreme Court of Errors and Appeals of Tennessee similarly wrote that state courts must enforce federal penal laws because "the laws of the United States... by solemn compact are as obligatory as those made by the State legislatures." " 80 For these courts, the argument that federal penal laws were not enforceable in state courts based on general jurisdictional principles was misplaced. ${ }^{181}$ Because, under the Supremacy Clause, federal law was the law of each state, state courts couldindeed, had to-enforce federal penal laws.

Some state judges who determined that the Supremacy Clause rendered state court jurisdiction of federal penal actions constitutional proceeded to identify prudential benefits of such jurisdiction. Specifically, they noted that state court jurisdiction of federal penal actions would afford defendants the convenience of a state court forum. It does not appear that any judge found state court jurisdiction of federal penal actions constitutional because it would be convenient to the defendant. Rather, judges who held that state court enforcement of federal penal actions was constitutional merely recognized that a state court trial would be more convenient for most defendants. The opinion of the Pennsylvania Supreme Court in Buckwalter v. United States ${ }^{182}$ is illustrative:

178. State v. Wells, 20 S.C.L. (2 Hill) 687, 695 (Ct. App. I835) (O'Neall, J.).

179. Id.

I80. Hartley v. United States, 4 Tenn. (3 Hayw.) 45, 60 (I8I6) (Roane, J.). Justice Haywood went on to ask a series of rhetorical questions about federal penal laws that we recognize today as invoking the "political safeguards of federalism":

Do we not make them ourselves? Do we not appoint the legislators and President? Are they not our representatives intrusted with the regulation and care of our interests, for the purpose of procuring the public welfare and prosperity? Are we not sworn to support them? 1s not our duty to obey and carry them into effect? Are we not bound in conscience and as good citizens, to aid in support of them?

Id. at 53 (Haywood, J., concurring).

I8I. Most of the cases to address the enforceability of federal penal laws in state courts during the first decades after the Constitution was adopted were decided in state courts, where the issue most naturally arose. In Stearns v. United States, 22 F. Cas. II 88 (C.C.D. Vt. I835) (No. I3,341), a federal circuit court addressed this issue. In determining that federal civil actions for penalties were enforceable in state courts, it emphasized that federal laws "are laws operating upon and binding on the same people as the government and laws of the several states." Id. at I192.

182. I1 Serg. \& Rawle 193 (Pa. 1824). In Hartley v. United States, 4 Tenn. (3 Hayw.) 45 (18I6), the Supreme Court of Tennessee explained that:

[T]he consequence of such refusal [to hear federal penal action] will be, that defendants, in all cases of suits commenced against them for a violation of the revenue laws, let their place of 
And although convenience is no justification for the usurpation of power, yet as the court does not see how this conflicts with the constitution of the United States, the inconvenience may be considered; and it would be an intolerable inconvenience and grievance, in an action for a petty penalty, to drag a man from the most remote corner of the state, to the seat of the federal judiciary. ${ }^{183}$

\section{Tennessee Supreme Court Justice John Haywood similarly explained:}

What has the defendant to complain of? His ease and convenience are consulted . . . his cause is left to a jury of his acquaintances and friends . . . . If the United States are willing that infractions of their penal laws shall be heard and adjudged in our own courts, shall we say no ${ }^{184}$

In his dissent in Lathrop, New York Justice Jonas Platt observed that congressional allowance of state court jurisdiction of certain penal actions was for the benefit of defendants, "rendering it more cheap and easy to defend themselves when sued for such penalties."185

It is no surprise that these judges commented upon this prudential benefit of state court jurisdiction of federal penal actions. Public officials had long invoked the inconvenience of federal courts in arguing against federal court jurisdiction as a constitutional and statutory matter. In 1788, in the Massachusetts ratifying convention, Anti-Federalist Abraham Holmes argued against the Constitution on grounds that federal criminal trials would not necessarily be held "in the vicinity where the fact was committed."186 This meant, in his view, that juries could not assess the "character of the person charged with the crime" or the "credibility of the witnesses," and "may be interested" in conviction. ${ }^{187}$ Likewise, a defendant " $m a y$, by reason of the distance of his residence from the place of trial, be incapable of making such a defence as he is, in justice, entitled to, and which he could avail himself of, if his trial was in the same county where the crime is said to have been committed." 188 The Federalist response

residence be ever so remote from the place of holding the district courts of the United States, will be deprived of the privilege of a trial in his own county, before a judge of his own State, and obliged, at great expense and trouble, to attend at the federal tribunals, as Congress have the power to give that court exclusive jurisdiction whenever it may become necessary.

Id. at 52 .

183. 11 Serg. \& Rawle at $196-97$.

184. Hartley, 4 Tenn. at 54 (Haywood, J.) (concurring in judgment).

185. United States v. Lathrop, 17 Johns. 4, 22 (N.Y. 1819) (Platt, J., dissenting); see also Hartley, 4 Tenn. at 49 (stating that Congress allowed state courts to exercise jurisdiction over the penal statute under consideration "for the convenience of the citizens").

186. 2 Debates On The Adoption Of The Federal Constitution 109-14 (Jonathan Elliot ed., 1888).

187. Id. at 110 (emphasis added).

188. Id.; see also The Address and Reasons of Dissent of the Minority of the Convention of Pennsylvania to Their Constituents, PA. PACKET \& DAILY AdVERTISER, Dec. 18, 1797, reprinted in 3 THE COMPLETE ANTI-FEDERALIST, supra note 83, at 160-61 (arguing that criminal defendant may be called to answer in a federal court "far from home," and "[t]hus an inhabitant of Pittsburgh, on a charge of crime 
was that Congress would not constitute federal courts in such a way that they would be inconvenient fora for the adjudication of federal crimes. John Marshall argued in the Virginia ratifying convention, for example, that there was no reason to think Congress would not provide for criminal prosecutions in federal courts "in such manner as will be most safe and convenient for the people." 189 The convenience issue arose in the First Congress in debates over what jurisdiction federal courts should have over federal crimes. Georgia Representative James Jackson argued, for instance, that it would be "vexatious to drag" a defendant "two or three hundred miles from his home, with evidences to try and give testimony at a distant place; every thing is to be dreaded from it." 190

In sum, public officials who argued that Congress could not constitutionally assign jurisdiction of federal penal actions to state courts (and even one judge who argued that such jurisdiction was constitutional ${ }^{191}$ ) relied on jurisdictional principles derived from the law of nations. Public officials who argued that Congress could constitutionally assign jurisdiction of federal penal actions to state courts generally relied on the Supremacy Clause as overriding general jurisdictional principles, with some noting the prudential benefits of state court jurisdiction to defendants charged with federal crimes. Again, the purpose of this analysis is not to evaluate the merits of these arguments; it is merely to show that constitutional arguments about the power of Congress to allow or require state court jurisdiction of federal actions relied on general jurisdictional principles of the law of nations, or specific constitutional provisions interpreted to displace them. The next section analyzes the application of this method of analysis to two specific questions of congressional power and state court jurisdiction that the Supreme Court has not definitively resolved.

\section{ISSUES IN CONTEMPORARY APPLICATION}

There are many questions one can imagine involving the relationship between congressional power and state court jurisdiction that the Supreme Court

committed on the banks of the Ohio, may be obliged to defend himself at the side of the Delaware, and so vice versa").

189. John Marshall, Speech at the Virginia Ratifying Convention (June 20, 1788), reprinted in $1 \mathrm{THE}$ Papers of John Marshall 275-85, (Herbert A. Johnson ed., 1975). Marshall argued:

"Will a man on the Eastern Shore, be sent to be tried in Kentuckey; or a man from Kentuckey be brought to the Eastern Shore to have his trial? A Government by doing this, would destroy itself. I am convinced, the trial by jury will be regulated in the manner most advantageous to the community."

Id. at 285 .

190. 1 Annals of Cong. 834 (Joseph Gales ed., 1790). As Jackson also put his point:

I know not how far in time a man might not be dragged; perhaps from the Oconee to be tried in North Carolina; for one part of the bill, without specifying the spot, declares, that the Circuit courts shall have power to hold special sessions for the trial of criminal causes at their discretion.

Id. at 847 .

191. See supra notes 173-81 and accompanying text (describing the views of New York State Supreme Court Justice Platt). 
has yet to resolve. This Part is concerned with questions regarding that relationship which recent federal initiatives have raised, specifically (1) whether Congress may allow or require state courts to enforce federal criminal laws; and (2) whether Congress may regulate state court jurisdiction in state law cases. The purpose of this Part is to demonstrate how the historical analysis would frame judicial consideration of these questions.

\section{A. STATE COURT JURISDICTION OF FEDERAL CRIMINAL ACTIONS}

As mentioned, the Judicial Conference of the United States and certain scholars have made calls in the last decade or so for Congress to assign certain federal criminal cases to state courts. In Testa v. Katt, the Supreme Court generally followed the historical method of analysis in resolving that Congress may constitutionally require state courts to hear federal actions for civil penalties. Whether Testa resolves that Congress may constitutionally require state courts to hear federal criminal actions remains a disputed question. This section, first, identifies the historical general law principles that bear on this question and, second, examines whether any specific constitutional provision plausibly operates to override them.

First, the historical debates described in Part II well illustrate how principles of general law would operate in this context. If the sovereignty interests that the law of nations recognized in a forum state not to enforce penal laws of other sovereigns inhere in states relative to the federal government, a state nuay refuse to enforce criminal actions arising under the laws of the United States. Thus, if general principles marked the relative powers of Congress and state courts in this regard, Congress niay not require a state court to enforce a federal criminal action. The question whether Congress may allow a willing state court to enforce a federal criminal action implicates interests of the United States in exclusively enforcing its own criminal laws. It is more difficult to definitively characterize the operation of general principles in this regard. ${ }^{192}$ As explained in Part II, most general-law-based arguments made in the decades surrounding ratification regarding state court jurisdiction of federal penal actions understood the general law to be that one sovereign could not enforce the penal laws of another-period. For example, in Jackson v. Rose, ${ }^{193}$ the General Court of Virginia explained that "there is no principle of Universal Law which authorises one Sovereign to empower ... the Judiciary of another" to enforce the former's penal laws. ${ }^{194}$ In contrast, in his dissent in Lathrop, Justice Jonas Platt argued that the practice of nations demonstrated only that one state could not enforce

I92. James Kent commented in his Commentaries on American Law on the difficulties that could obtain in identifying the precise content of the law of nations: "[A]s the precepts of this code [the law of nations] are not defined in every case with perfect precision, and as nations have no common civil tribunal to resort to for the interpretation and execution of this law, it is often very difficult to ascertain." 1 KENT, supra note 119 , at 2 .

193. 4 Va. (2 Va. Cas.) 34,36 (1815).

194. Id. 
another's penal laws without the other's consent. This is a crucial distinction. To the extent that general law defines the relationship between Congress and state courts in this regard, Jackson's characterization of general law would preclude voluntary federal-state cooperation in the judicial enforcement of federal criminal laws, while Justice Platt's characterization would allow it. Neither characterization would be difficult to apply in practice. The difficulty lies in determining which characterization is the proper one. Did the practice of nations in not enforcing penal laws of another evidence a belief that they never could do so, or that they could not do so without consent of the other? The dearth of historical instances of such consent, let alone judicial discourse about it, leaves us with no clear answer to this question. If the only justification for the penal law exception was that it enabled the state that created a criminal liability to effect its own penal policies, ${ }^{195}$ there would seem to be little reason why one state could not choose to leave the enforcement of its criminal laws to another. Given, however, the other justifications that courts and treatise writers provided to explain the penal law exception, for example, that a pardon power should exist with respect to every crime, ${ }^{196}$ the question is more complicated.

The next question for consideration under the historical framework would be whether any provision of the Constitution specifically alters the relationship between Congress and state courts as the general law, properly construed, would define it in this context. In the landmark case of Testa v. Katt ${ }^{197}$ the Supreme Court held that the Supremacy Clause specifically authorized Congress to require state courts to enforce a federal civil "penal" action, notwithstanding sovereignty interests that the law of nations otherwise might have recognized in this context. As a method of constitutional analysis, the historical framework finds precedential support in Testa. The question is whether, in employing this framework, Testa resolved whether Congress may require or allow state courts to enforce federal criminal actions. Testa, to be sure, contains sweeping language that arguably renders general principles inapposite to the constitutional relationship between congressional power and state court jurisdiction in any federal penal action, be it civil or criminal. ${ }^{198}$ As will be discussed, however, this language in Testa went far beyond the scope of the actual decision the Court was called upon to make. Moreover, it did not address other structural constitutional principles that, though inapposite to the civil case before the Court, directly bear on the criminal jurisdiction question.

To understand Testa, we must appreciate the history of judicial opinion that preceded it on the question it addressed. As explained in Part II.B, Justices

I95. See supra notes 59-6I and accompanying text.

196. See supra notes $63-64$ and accompanying text.

197. 330 U.S. $386,393-94$ (1947).

198. See Testa, 330 U.S. at 389-90 (rejecting, "the supremacy clause considered," the general law-based argument that Rhode Island courts did not have to hear federal penal actions, and explaining that early Congresses "conferred on the states jurisdiction over federal crimes and actions for penalties and forfeitures"). 
Joseph Story and John McLean argued in the early nineteenth century that state tribunals could not enforce federal criminal laws. ${ }^{199}$ In the late nineteenth century, the Court addressed whether state courts could enforce federal penal laws in Claftin v. Houseman ${ }^{200}$ and Huntington v. Attrill, ${ }^{201}$ answering the question differently in each case, albeit in dicta. In Claflin, decided in 1876, the Court addressed whether an assignee under federal bankruptcy law could sue in state court for assets that the assignment had vested in him. ${ }^{202}$ In addressing this issue, the Court explained that "[i]f an act of Congress gives a penalty to a party aggrieved, without specifying a remedy for its enforcement, there is no reason why it should not be enforced, if not provided otherwise by some act of Congress, by a proper action in a State court."203 Sixteen years later, in Huntington, the Court described this aspect of Clafin as dicta. ${ }^{204}$ In Huntington, the Court addressed whether one state had to enforce a statute of another state that was alleged to be penal in the international sense. In addressing this issue, the Huntington Court expressed the view that "the courts of a state cannot be compelled to take jurisdiction of a suit to recover a like penalty for a violation of a law of the United States."205

In Testa v. Katt, ${ }^{206}$ the Court adopted the analysis of Clafin, relegating Huntington to a footnote. ${ }^{207}$ The issue in Testa was whether Congress had the power to require state courts to enforce the federal Emergency Price Control Act. ${ }^{208}$ The Act provided that a plaintiff could recover treble damages against a defendant who violated the price ceiling that the Act prescribed. Rhode Island courts refused to enforce the law on the ground that it was "penal," one

199. See supra, notes $130-33$.

200. 93 U.S. $130,133(1876)$.

201. 146 U.S. $657,685-86$ (1892).

202. Claflin v. Houseman, 93 U.S. 130, 133 (1876).

203. 93 U.S. at 137. Three years after the Court decided Clafin, it held in Tennessee v. Davis, 100 U.S. 257 (1879), that Congress has the constitutional power to provide for the removal of criminal prosecutions in state courts against federal revenue offlcers involving their official acts. That Congress may provide for the enforcement of state criminal prosecutions that raise certain federal questions in federal courts does not necessarily mean that it may allow for the enforcement of any federal criminal prosecution in state court. The Davis Court justified its decision on the ground that "when the Constitution was adopted, a portion of [state] judicial power became vested in the new government created, and so far as thus vested it was withdrawn from the sovereignty of the State." Id. at 267. Specifically, the Constitution gave Congress power to confide the judicial determination of all federal questions to federal courts. Id. That Congress has power to confide the judicial determination of all federal questions to federal courts does not necessarily mean that it may allow for the judicial determination of any kind of federal question by state courts.

204. According to the Huntington Court, the only "point adjudged was that an assignee under the bankrupt law of the United States could assert in a state court the title vested in him by the assignment in bankruptcy." 146 U.S. at 672.

205. Id.

206. 330 U.S. 386 (1947).

207. Huntington, the Testa Court explained, involved a question of whether one state had to enforce not a federal law, but the law of another state, and, thus, what it said about a state's obligation to enforce federal law was dicta. See id. at 393 \& n.11.

208. See id. at $387,391$. 
sovereign having no obligation to enforce the penal laws of another. ${ }^{209}$ The Testa Court rejected "the basic premise" that a state "has no more obligation to enforce a valid penal law of the United States than it has to enforce a penal law of another state or a foreign country." ${ }^{210}$ The Court held that such a premise "disregards the purpose" of the Supremacy Clause. ${ }^{211}$ It reasoned that when Congress enacts a statute, it establishes a policy that "is as much the policy of [a State] as if the act had emanated from its own legislature, and should be respected accordingly in the courts of the state." 212 For historical support, the Court cited statutes of the first Congresses "conferr[ing] on the states jurisdiction over federal crimes and actions for penalties and forfeitures." 213 To the extent that other historical evidence suggested that these statutes were unconstitutional, the Testa Court determined that Clafin repudiated its force. ${ }^{214}$

Some scholars have argued that Testa definitively resolves that Congress may require state courts of competent jurisdiction to adjudicate any kind of federal action-be it civil or criminal. ${ }^{215}$ Others have argued that Testa does not resolve whether Congress may require state courts to hear federal criminal actions, as opposed to federal actions for civil penalties. ${ }^{216}$ There are two reasons why we should hesitate before characterizing Testa as resolving that Congress may require state courts to hear federal criminal actions. First, to the extent that the Testa Court premised its opinion on a historical understanding of the Constitution, the case did not involve a law that necessarily would have qualified as a "penal" one at the time that the Constitution became law. The action that Testa considered was one by a private citizen to recover treble damages from another private citizen. As explained in Part I.B.1, courts had not settled in the late eighteenth and the early nineteenth centuries that such a law qualified as a penal one in the international sense. ${ }^{217}$ To the contrary, English sources suggested otherwise. ${ }^{218}$ Indeed, in 1876, in Huntington, the Supreme Court itself defined "penal laws" as "those imposing punishment for an offense committed against the state, and which ... the executive of the state has the power to pardon."219

209. See id. at $387-88$.

210. Id. at 389 .

211. $I$.

212. Id. at 392 (quoting Mondou v. N.Y., New Haven \& Hartford R.R. Co., 223 U.S. 1, 57 (1912)).

213. Id. at 390 \& n.5.

214. Id. at 390-9I.

215. See, e.g., Beale, supra note 10, at 1012 ("While Testa involved treble damages rather than a traditional criminal prosecution, its broad language and reasoning appIy equally well to the latter."); Mengler, supra note 10, at 536 ("States ... are now and have been for some time required to hear federal civil cases, and there is no apparent reason to distinguish criminal cases from civil cases.").

216. See, e.g., Adam H. Kurland, First Principles of American Federalism and the Nature of Federal Criminal Jurisdiction, 45 EMORY L.J. 1, 71 (1996) (“[D]espite [Testa's] sweeping dicta, the Court's characterization of the claim as 'penal' in a general sense cannot be extrapolated to mean that federal criminal prosecutions in state court are constitutionally permissible.").

217. See supra notes $44-51$ and accompanying text.

218. See supra note 44 and accompanying text.

219. Huntington v. Attrill, 146 U.S. 657, 667 (1892). 
Under this definition, a law providing that a plaintiff may recover treble damages in a private action would not qualify as a "penal" one. Accordingly, if one reads Testa for what it did, rather than for all that it said, its analysis arguably does not embrace criminal actions.

There is a second reason why we should hesitate before characterizing Testa as establishing that Congress may require state courts of competent jurisdiction to enforce federal criminal actions, again, as opposed to federal actions for civil penalties. The Testa Court primarily considered whether the Supremacy Clause overrides any general-law-based sovereignty interest that a state might have in not enforcing a federal action for a civil penalty. It did not consider whether the Supremacy Clause (or any other provision of the Constitution) overrides any general-law-based interest that the United States might have in exclusively enforcing its own criminal laws.

Recall the several interests of the United States in exclusively enforcing its own criminal laws that public officials historically identified: (1) preventing state court frustration of federal penal policy by courts unaccountable to the United States; (2) enforcing and receiving the penalties that federal criminal laws impose; and (3) maintaining an effective unitary pardon power in the President. ${ }^{220}$ The first interest does not seem particularly compelling in this context. Congress is responsible for federal penal policy; if it determines that such policy would be best served by state courts enforcing federal criminal laws, it would be strange to say that state court enforcement would frustrate federal penal policy. ${ }^{221}$ Congress always has power to render federal court

220. See supra notes 143-75 and accompanying text. As in Testa, the Court did not address these interests in Palmore v. United States, 411 U.S. 389 (1973), which held that Congress may vest jurisdiction of criminal cases local to the District of Columbia in judges who do not have life tenure and protection against salary reduction that Article III judges have. See id. at 390 . While the Palmore opinion contains some broad language in dicta regarding the constitutional ability of state courts to hear federal criminal cases, see id. at 402, the Court did not address any of the federal interests that historically were put forward against the constitutionality of state court jurisdiction of federal crimes. The trial of crimes local to the District of Columbia by non-Article III judges does not implicate any of these interests for the following reasons: (1) Congress controls both the making and enforcement of policy for the District of Columbia; (2) penalties against District of Columbia laws are owed to federally controlled entities, and federally controlled officers enforce them; and (3) the President has sole power to pardon offences committed against the criminal laws that govern the District.

Nor were these interests implicated in Tennessee v. Davis, 100 U.S. 257 (1879). In Davis, the Court held that Congress could authorize removal to federal courts of state criminal actions brought against officers of the United States. The Court held that since Article III extended the judicial power to cases "arising under" federal law, and this was a case "arising under" federal law, Congress had power to give federal courts jurisdiction over it. Id. at 263-64. This case did not involve any constitutional interests of the United States in federal enforcement of its own criminal laws; it involved only the interest of a state in enforcing its own criminal laws, an interest that the Court held Article III divested in state law criminal cases arising under federal law.

221. On the other hand, the first federal interest may seem weak in this context, at least as a constitutionally protected one. The argument, recall, was that federal courts must have exclusive jurisdiction of federal penal laws because state court enforcement could operate to frustrate federal policy. See supra notes 143-49 and accompanying text. The typical general law situation, however, was Sovereign A enforcing the penal laws of Sovereign B without Sovereign B's consent. There was an 
enforcement of federal criminal laws exclusive-as, indeed, federal court enforcement currently is-if Congress determines that exclusive federal court enforcement would best serve federal penal policy. Other interests of the United States, however, are at stake.

Consider the second interest that public officials historically identified in arguing that federal courts must have exclusive jurisdiction of federal criminal laws: that the United States be the sovereign to recover monetary penalties for federal penal violations, and to imprison federal offenders. These interests involve not merely the interests of Congress in setting federal criminal policy, but the interests of the President in enforcing federal criminal laws. First, there would be a potential constitutional problem with state court jurisdiction of federal criminal actions if Congress left the enforcement of the judgments that state courts entered in such cases to state executive officials. The Constitution provides that the President "shall take Care that the Laws be faithfully executed." 222 In Printz v. United States, ${ }^{223}$ the Court held that it would violate separation of powers for Congress to transfer responsibility to enforce federal laws from the President to the states:

The insistence of the Framers upon unity in the Federal Executive-to ensure both vigor and accountability-is well known.... That unity would be shattered, and the power of the President would be subject to reduction, if Congress could act as effectively without the President as with him, by simply requiring state officers to execute its laws. ${ }^{224}$

There is no obvious reason why this analysis would not apply to state executive enforcement of federal penal judgments-typically, collecting penalties and incarcerating offenders. It is true that state executive officials liave long en-

open question whether one sovereign could consent to another's enforcing its penal laws. If such consent was valid as a matter of general law, the general law objection would disappear.

Moreover, unlike in the general law situation, state courts are accountable to the Umited States in ways that the courts of one nation were not usually accountable to the courts of another. One way in which state courts are accountable to the United States for their actions in adjudicating federal penal actions is through Supreme Court review. Congress has power to authorize the Supreme Court to review state court judgments of conviction in federal penal actions. Congress may not, however, authorize Supreme Court review of state court judgments of acquittal in federal penal actions for double jeopardy reasons. Thus, congressional power to hold state courts accountable in the Supreme Court for federal law determinations is more limited in criminal than in civil cases. That said, there remains a sigmificant federal check on state court enforcement of federal penal actions. Congress always has power to withdraw state court jurisdiction of such actions altogether and vest it exclusively in federal courts-indeed, federal law currently renders federal court jurisdiction of federal criminal actions exclusive. In light of these federal checks on state court enforcement of federal penal laws, it would be awkward to argue that general law principles as understood at the Founding should operate to preclude state court enforcement of federal criminal law for the specific reason that such enforcement could operate to frustrate federal penal policy.

222. U.S. Const. art. II, \& 3.

223. 521 U.S. 898 (1997).

224. Id. at $922-23$ (citation omitted). 
forced state court judgments premised on federal civil laws, just as they have long enforced judgments premised upon foreign laws. A scheme that left enforcement of judgments upon federal crimes solely to state executive officials, precluding the federal executive from enforcing federal criminal laws, would be not only unprecedented as a matter of general law, but also possibly unconstitutional under the reasoning of Printz.

It would not be a perfect solution to this problem for Congress simply to provide for federal executive enforcement of judgments that state courts would enter in federal criminal cases. A court typically must exercise some form of coercive authority over executive officials that execute its judgments. Suppose that a state court directed a federal executive agency or official to collect a fine or imprison an offender, and the agency or official did not comply to the state court's satisfaction. Could the state court constitutionally call the federal executive to the state bar to answer for the alleged neglect in the enforcement of federal law? In the Nation's early history, the Supreme Court held that state courts could not issue writs of mandamus against federal officers to compel them to perform their duties, ${ }^{225}$ nor could they issue writs of habeas corpus against federal officials. ${ }^{226}$ Though state courts generally may enter damages awards against federal officials, the weight of state and lower federal court authority is that Congress may not enter injunctive orders against federal officials. ${ }^{227}$ This is not to say that state courts categorically may not hold federal executive officials to account for failing to properly execute federal criminal judgments; it is only to say that whether state courts could do so is a complicated question, one that Testa certainly did not address in its broad dicta.

The third general-Iaw-related federal interest that exclusive federal court jurisdiction of federal penal actions arguably serves is preserving the President's unitary and effective pardon power. As explained, the idea of one sovereign creating a criminal law and another enforcing it was thought to create a puzzle with respect to the pardon power: Who has the pardon power-the sovereign creating the law, the sovereign enforcing it, or both? The Constitution confers on the President "Power to grant Reprieves and Pardons for Offenses against the United States." 228 If, according to this text, the President holds a pardon power over all federal offenses, state court jurisdiction and/or enforcement of federal criminal laws could render the President's pardon power less effective.

The President's pardon power would be less effective, first, if a state also maintained a pardon power when its courts enforced federal criminal judgments. More specifically, the President's pardon power would be less effective

225. See McClung v. Silliman, 19 U.S. (6 Wheat.) 598, 604-05 (1821).

226. See Tarble's Case, 80 U.S. 197 (1871); Ableman v. Booth, 62 U.S. (21 How.) 506, 523-25 (1859).

227. See Martin H. Redish \& Curtis E. Woods, Congressional Power To Control the Jurisdiction of Lower Federal Courts: A Critical Review and a New Synthesis, 124 U. PA. L. Rev. 45, 88-90 (1975) (citing decisions that deny state court power to enter injunctive orders against federal officials).

228. U.S. Const. art. II, $\S 2$. 
insofar as the President would not have exclusive authority to determine who should be pardoned of federal offences. In 1896, Justice Field wrote that Congress may not give pardons because "a pardon is an act of grace which is, so far as relates to offenders against the United States, the sole prerogative of the president to grant." ${ }^{229}$ The President's pardon power also could be less effective even if no state entity had a pardon power over the same crime. If a state court tried and sentenced a defendant charged with a federal crime, the President might not be as well-positioned to assess the fairness of the trial and sentence as the President would be if a federal court had tried and sentenced the offender. More significantly, if the state executive was the authority to enforce the judgment, the President might not be as well-positioned to assess the conditions of confinement and rehabilitation of the offender as the President would be if he was the enforcing authority.

The Supreme Court has explained that the pardon power of the President "is not subject to legislative control. Congress can neither limit the effect of his pardon, nor exclude from its exercise any class of offenders. The benign prerogative of mercy reposed in him cannot be fettered by any legislative restrictions." ${ }^{, 30}$ Whether it would unconstitutionally fetter the President's pardon power for Congress to place individuals subject to the President's pardon power in the custody of a state court or executive system is a question that the Court has never addressed. At the time that the Constitution was ratified, the law of nations presumed that the sovereign that created a criminal law would be the sovereign to enforce it, and, when appropriate, pardon those who violated it. If the Constitution captures this same understanding, these constitutional questions are avoided.

ln sum, Testa is best taken-notwithstanding its sweeping dicta-as having resolved only that, in light of the Supremacy Clause, Congress may require state courts to enforce civil damages actions brought under federal law, including actions for civil penalties. If a court were to invoke the historical framework in analyzing questions of state court jurisdiction of federal criminal actions, the landscape would emerge as follows. Under general principles, as they were recognized at the time the Constitution became law, Congress could not require state courts to enforce federal criminal actions. It is not obvious, however, whether under general principles Congress could allow a consenting state to enforce federal criminal laws. As for whether the Supremacy Clause overrides the operation of general principles (however properly construed), structural constitutional difficulties emerge relating to the constitutional prerogatives of the federal executive in the enforcement of federal criminal law. That the questions are difficult, however, does not diminish the viability of the historical

229. Brown v. Walker, 161 U.S. 591, 638 (I896) (Field, J., dissenting).

230. Ex parte Garland, 71 U.S. 333, 380 (1866); see also United States v. Klein, 80 U.S. (13 Wall.) 128,141 (1871) (stating that 'the President's power of pardon 'is not subject to legislation;' that 'Congress can neither limit the effect of his pardon, nor exclude from its exercise any class of offenders"' (footnote omitted)). 
analysis as a means of identifying and framing them.

\section{B. STATE COURT JURISDICTION OF STATE LAW ACTIONS}

This section considers how the historical analysis might frame questions of congressional power to regulate state court jurisdiction in state law cases. The general-law-based framework that this Article describes framed debates in early American history over the power of Congress to require or allow state courts to exercise jurisdiction over actions arising under federal law. An initial question is whether this framework is relevant to questions regarding the power of Congress to regulate state court jurisdiction over actions arising under state law.

The framework is relevant to these questions. General law principles have operated as a baseline in historical discussions regarding the competence and duties of state courts to enforce not only federal law, but state law as well. Since the time that the Constitution was ratified, courts have considered the extent to which the Full Faith and Credit Clause ${ }^{231}$ leaves in place general-law-based sovereignty interests of state courts in the enforcement of laws of other states, and the extent to which the Full Faith and Credit Clause overrides those interests. For example, an issue that immediately arose in state courts after the Constitution became law was whether the judgment of one state was conclusive or merely prima facie evidence of a debt in the courts of another state. Some state courts held that just as the judgment of a court of a foreign nation was merely prima facie evidence of the debt, so too was the judgment of a sister state. ${ }^{232}$ Other state courts held that the Full Faith and Credit Clause altered the general law principle as it previously operated in state courts, requiring that state courts treat judgments of sister states as conclusive evidence of the debt. ${ }^{233}$

23I. See U.S. Const. art. IV.

232. See, e.g., Hitchcock v. Aiken, 1 Cai. 460, 478 (N.Y. 1803) (Radcliff, J.) ("I am, therefore, of opinion, that the judgments of other states are to be considered in the light of foreign judgments, and, when made the foundation of a suit in our own courts, are not conclusive, but, from courtesy, are to be admitted as presumptive evidence only of a title to recover, according to our own laws." (emphasis added)); id. at 483 (Kent, J.) ("The result of my opinion is, that the judgment in question is to be considered in the light of a foreign judgment, and only prima facie evidence of the demand."); Hammon \& Hattaway v. Smith, 3 S.C.L. (1 Brev.) 110 (Const. App. 1802) (Grimke, J., concurring) ("This article only declares, that it shall be received with full faith and credit; but it does not say that it shall be the foundation of the suit: evidently meaning to draw a distinction between the effect it would have, as evidence of such a debt, and the recovery thereof, and that of its being full and unequivocal proof of the debt."); Winchester v. Evans, 3 Tenn. (Cooke) 420, 429 (1813) ("And if the defendant can clearly show, upon the merits, that such a judgment, when the whole truth is known, ought never to have been pronounced, I would consider myself at liberty to grant him relief.").

233. Some state courts held that a sister state judgment should have the same validity and effect it would have in the issuing court. See, e.g., Rogers v. Coleman, $3 \mathrm{Ky}$. (Hard.) 413, 415 (1808) ("To give such faith and credit to the records abroad, as they would have at home, is certainly giving them 'full faith and credit.' The [C]onstitution of the Umited States can require no more; and the law of [C]ongress on the subject... can mean no more nor less."); Curtis v. Gibbs, 2 N.J.L. 399, 405 (1805) ("[T] records and judicial proceedings in the courts of justice in the State of Pennsylvania, or any other State in the Union, must have the same faith and credit given them in this State, as they are entitled to by law or usage in the courts of the State from which they are brought."); Wade v. Wade, 1 N.C. (Cam. \& Nor.) 
In Mills v. Duryee ${ }^{234}$ the Supreme Court resolved that under the Full Faith and Credit Clause judgments of the courts of one state are "conclusive" upon the courts of another. ${ }^{235}$ With respect to other matters, the Supreme Court has held that the Full Faith and Credit Clause left the general law in place as it governed the obligations of one state to enforce the judgments of another. For example, state courts generally agreed after the Constitution became law that the Full Faith and Credit Clause left in place the general jurisdictional principle that a forum state could inquire into whether a foreign court had jurisdiction to enter a judgment sought to be enforced in the forum court. ${ }^{236}$ The Supreme Court has confirmed this understanding. ${ }^{237}$ If there are limits on congressional authority to regulate state court jurisdiction in federal law cases, they would seem to obtain all the more in cases in which federal law provides no rule of decision-subject, of course, to any specific constitutional provisions that override the operation of general jurisdictional principles of the law of nations.

There is no historical record specifically addressing what power Congress has to provide jurisdictional rules for state courts in purely state law cases. Congress has never set jurisdictional rules for state courts in such cases, and no public official appears to have contemplated the possibility that Congress might do so during the Founding period or the first decades thereafter.

Today, legislative initiatives have emerged in Congress that would set jurisdictional rules for state courts in purely state law cases. In 2004, the House of Representatives passed the Lawsuit Abuse Reduction Act of 2004 (LARA), ${ }^{238}$ a bill that was reintroduced in Congress this past year. ${ }^{239}$ This Act provides a useful case study for this section. LARA, a "tort reform" neeasure, provides that plaintiffs may bring personal injury clainıs only in specified jurisdictions. The purpose of the bill is to limit the ability of plaintilfs to bring personal injury

601,602 (1804) ("The record of the judgment in question is entitled to the same faith and credit in the court as it is entitled to in the courts of the State from whence it came."). Other state courts held that a sister state judgment should have the same validity and effect that a judgment of the enforcing court would have in similar circumstances. See, e.g., Wilson v. Robertson, 1 Tenn. (1 Overt.) 266, 268 (1808) ("Hence, it results that our courts seem disposed to consider the judgment of another State in the same poimt of view with a judgment of our own under similar circumstances.").

234. 11 U.S. (7 Cranch) 481 (1813).

235. Id. at 484.

236. See, e.g., Rogers, $3 \mathrm{Ky}$. (Hard.) at 417-18 ("All rights are growing out of, or attached to the person, or things, which are the subjects of property: and the jurisdiction of every court, must attach, either because the person is within the sphere of its authority; or because the property or effects of the person, or that which is the subject matter of the controversy, is within that sphere."); Bissell v. Briggs, 9 Mass. (8 Tyng.) 462, 468 (1813) (Parsons, C.J.) ("In order to entitle the judgment rendered in any court of the United States to the full faith and credit mentioned in the federal constitution, the court must have had jurisdiction, not only of the cause, but of the parties.").

237. See Nevada v. Hall, 440 U.S. 410, 421 (1979) ("A judgment entered in one State must be respected in another provided that the first State had jurisdiction over the parties and the subject matter.").

238. H.R. 4571, 108th Cong. (2004).

239. H.R. 420, 109th Cong. (2005). 
claims in "plaintiff friendly" jurisdictions. ${ }^{240}$ Specifically, the Act provides:

[A] personal injury claim filed in State or Federal court may be filed only in the State and, within that State, in the county (or Federal district) in which-

(1) the person bringing the claim, including an estate in the case of a decedent and a parent or guardian in the case of a minor or incompetent-

(A) resides at the time of filing; or

(B) resided at the time of the alleged injury; or

(2) the alleged injury or circumstances giving rise to the personal injury claim allegedly occurred; or

(3) the defendant's principal place of business is located. ${ }^{241}$

In other words, a plaintiff may file a personal injury claim only in one of three jurisdictions: (1) the state in which the plaintiff resides at the time of filing or resided at the time of the injury, (2) the state in which the alleged injury or circumstances giving rise to the claim allegedly occurred, or (3) the state in which the defendant's principal place of business is located. In many (probably most) cases, a plaintiff would choose to file in a state that satisfied one of those criteria regardless of LARA. In some cases, however, a plaintiff would choose to file elsewhere (the purpose of the legislation, after all, is to prevent a plaintiff from filing suit in a jurisdiction in which the plaintiff otherwise could file). For instance, the Act would preclude, absent satisfaction of one of its jurisdictional criteria, a plaintiff from filing a lawsuit in a state in which a natural-person defendant resides, is domiciled, or is otherwise physically present, or in a state in which an artificial-person defendant has a sufficient presence for a state to exercise personal jurisdiction over it but has its principal place of business elsewhere. (The Supreme Court has held that, as a matter of due process, a state generally may exercise personal jurisdiction over those physically present within its territory, ${ }^{242}$ or having "minimum contacts" with the state. ${ }^{243}$ ) The filing of lawsuits in such jurisdictions is commonplace. ${ }^{244}$

The Act thus has two effects that are relevant to the present inquiry. First, it may require a plaintiff to file a case in a forum in which the plaintiff might otherwise choose not to file it. Second, the Act may preclude a state in which the plaintiff might otherwise choose to file a case from exercising jurisdiction

240. See H.R. ReP. No. 109-123, at 3-4 (2005).

241. H.R. 420, 109th Cong. § 4(a) (2005).

242. See Burnham v. Superior Court, 495 U.S. 604, 619 (1990) (plurality opinion) (holding that "jurisdiction based on physical presence alone" does not violate due process).

243. See Int'1 Shoe Co. v. Washington, 326 U.S. 310, 316 (1945) ("[D]ue process requires only that in order to subject a defendant to a judgment in personam . . . he [must] have certain minimum contacts with [the foruni] ....").

244. See, e.g., Dahmes v. Champagne Elevators, Inc., 869 So. 2d 904, 909 (La. Ct. App. 2004) (exercising personal jurisdiction in personal injury case over defendant with principal place of business in North Carolina); Boris v. Bock Water Heaters, Inc., 775 N.Y.S.2d 452, 455-56 (N.Y. Sup. Ct. 2004) (exercising personal jurisdiction in personal injury case over defendants with principal places of business in Ohio and Wisconsin). 
over the case. If this Act, or another proposal like it, becomes law, courts potentially will be confronted with the question whether either of these effects is constitutionally problematic. This Part considers the sovereignty interests that general principles would have recognized (1) in states that Congress would make a lawful forum for the adjudication of state claims and (2) in states that Congress would make an unlawful forum for the adjudication of state claims. It also considers whether any provisions of the Constitution empower Congress to override these interests.

\section{Interests of a State Made a Lawful Forum}

The first question is whether a state that Congress makes a lawful forum for the adjudication of a state law case has any sovereignty interest against being made a lawful forum. As a matter of general law, each state would be a proper forum for the adjudication of transitory actions brought by a plaintiff against a defendant over which the state court had jurisdiction. ${ }^{245}$ That a state had power to enforce transitory actions did not mean, however, that it had a duty to do so. Accordingly, a state could have refused to adjudicate such actions.

That said, the Full Faith and Credit Clause imposes an affirmative obligation on states to enforce actions arising under the laws of other states. Under the Full Faith and Credit Clause, a state must give "Full Faith and Credit ... to the public Acts, Records, and judicial Proceedings of every other State."246 The Supreme Court has long held that one state has a "constitutional obligation to enforce the rights and duties validly created under the laws of other states."247 As others have argued, the Supreme Court's interpretation of the Full Faith and Credit Clause appears to be faithful to original understandings of the Clause. ${ }^{248}$ Accordingly, for Congress to provide that a plaintiff may bring an action arising under one state's laws in the courts of another is for Congress to require nothing that the plaintiff may not have chosen absent the regulation.

An issue might arise if Congress required State $A$ to exercise jurisdiction over an action arising under the laws of State $B$ that was penal in nature or against a public policy of State $A$. Under general principles, one state could refuse to exercise jurisdiction over such actions. Since the time of the Founding, the Full Faith and Credit Clause has been interpreted to leave this state prerogative in place. ${ }^{249}$ Accordingly, if general principles frame congressional power over state court jurisdiction, Congress might exceed its constitutional powers by

245. See supra Part I.A.

246. U.S. Const. art. IV, \& 1.

247. Hughes v. Fetter, 341 U.S. 609, 611 (1951). Cf. Wells v. Simonds Abrasive Co., 345 U.S. 514, 516 (1953) (explaining that "[ $t]$ he Full Faith and Credit Clause does not compel a state to adopt any particular set of rules of conflict of laws; it merely sets certain minimum requirements which each state must observe when asked to apply the law of a sister state").

248. See generally Kurt H. Nadelmann, Full Faith and Credit to Judgments and Public Acts, 56 Mich. L. Rev. 33 (1957); James D. Sumner, Jr., The Full-Faith-and-Credit Clause-Its History and Purpose, 34 OR. L. Rev. 224 (1955).

249. See Robert A. Leflar et al., American Conflicts Law 143-45 (4th ed. 1986). 
requiring states to exercise jurisdiction over such actions. It is worth pointing out, however, that LARA appears to impose no such requirement on state courts. It identifies jurisdictions in which a plaintiff may file a personal injury case, but does not appear to require a state court to exercise a jurisdiction that it would not exercise if the plaintiff had chosen that jurisdiction absent the federal regulation. Moreover, it is the rare case in which a state court may properly refuse to enforce the laws of another on public policy grounds. Since the time of the Founding, the Supreme Court has significantly narrowed the categories of public policy grounds on which a state court may refuse to enforce the laws of another. ${ }^{250}$ Under conflicts law today, the fact that a forum state has a public policy in conflict witl the law of another jurisdiction provides a valid reason for the forum state to apply its own law. ${ }^{251}$ Accordingly, it would be the rare case in which a state could object on public policy grounds that Congress had required it to take jurisdiction of a case to which another state's law constitutionally could apply.

In sum, the historical framework appears to operate with a reasonable degree of certainty and predictability as regards the interests of a state made a lawful forum for the adjudication of a state law claim. Under general principles, a state would have a prerogative not to enforce actions arising in or under the laws of other states. The Full Faith and Credit Clause overrides such principles with respect to all actions except penal ones and ones that would pose a legitimate public policy conflict for the forum state. Thus, only if Congress required State $A$ to enforce a penal law of State $B$ or other law of State $B$ that violated a public policy of State $A$ could State $A$ have any constitutional objection to the regulation based on general principles of law.

\section{Interests of a State Made an Unlawful Forum}

The next question is whether a state that Congress makes an unlawful forum for the adjudication of a state law case has any sovereignty interest against being made an unlawful forum. Two general jurisdictional principles are relevant to this question.

First, as explained in Part I, under general principles, the judicial authority of a state extended to the legal relations of persons present in the State, as well as to the legal relations of citizens, whether present or not. LARA would operate in certain cases to divest states of jurisdiction over the legal relations of persons present in or citizens of states. There is a significant question regarding how this principle should be cliaracterized today. At the time of the Founding, courts understood the constitutional jurisdiction of state courts to extend only to the legal relations of persons present within the state's territory or citizens. Today, the Supreme Court recognizes a state's constitutional jurisdiction to extend to defendants that have "certain minimum contacts with it such that the mainte- 
nance of the suit does not offend traditional notions of fair play and substantial justice."252 "Minimum contacts" analysis expands the general law understanding that a sovereign's prerogative to exercise judicial jurisdiction extended only to citizens or those physically present in the state. ${ }^{253}$ It is not immediately clear, in light of this shift in understanding, how courts should characterize the sovereignty interest that the general law recognized. If we read historical materials to protect from federal interference all the jurisdiction that state courts constitutionally may exercise over litigants in state law cases (that is, cases in which the defendant has minimum contacts with the state), we will protect more state jurisdictional power from federal interference than the operation of general principles would have protected at the time the Constitution became law. If we read historical materials to protect from federal interference only the jurisdiction that state courts constitutionally may exercise over state citizens and persons present in the state, we will protect less state jurisdictional power from federal interference than the Court has recognized that state courts constitutionally may exercise today.

There is a second general jurisdictional principle that is relevant to the question whether Congress may divest a state court of jurisdiction over state law cases. As explained in Part I, at the time of the Founding, a sovereign could render an action local by statute if the statute provided a general hability regarding a local matter and a special remedy to be enforced in a forum of that sovereign. ${ }^{254}$ Though the Supreme Court has narrowed the circumstances in which a state must give Full Faith and Credit to such a regulation, ${ }^{255}$ states continue to recognize a limited prerogative in other states to confine actions to their own courts. In Wilson v. Celestial Greetings, for example, the Missouri Court of Appeals held that a Delaware statute providing appraisal rights that certain dissenting shareholders could enforce only in Delaware Chancery Court created a "local cause of action" that shareholders could bring only in Delaware Chancery Court. ${ }^{256}$ Although, the Missouri court explained, a state generally may not "confine to its own courts" the enforcement of transitory actions, Delaware could do so here because the shareholders had in effect a claim based upon a contract, of which the special remedy was a constructive part. ${ }^{257}$ In a given case, a regulation like LARA could operate to preclude a state from rendering an action local unto itself that under general principles it historically could have rendered local unto

252. Int'l Shoe Co. v. Washington, 326 U.S. 310, 316 (1945) (internal quotation marks and citations omitted).

253. See id. (describing the evolution of the Supreme Court's personal jurisdiction jurisprudence).

254. See supra notes $65-70$ and accompanying text.

255. See Crider v. Zurich Ins. Co., 380 U.S. 39, 41-42 (1965) (holding that Alabama courts could award damages under Georgia's workers' compensation statute to an Alabama resident injured in Alabama even though the Georgia statute provided that only a particular Georgia tribunal could enforce the remedy).

256. Wilson v. Celestial Greetings, Inc., 896 S.W.2d 759, 761-62 (Mo. Ct. App. 1995).

257. Id. For an analysis of this kind of statute in another context, see Second Circuit and New York Courts Split on Whether Venue Provision of Louisiana Statute Authorizing Direct Action Against Insurers Limits Enforcement of Statute to Louisiana, 105 U. PA. L. REv. 745 (I957). 
itself. It may be unlikely that LARA itself will produce this result, as it allows jurisdiction in the state in which an injury occurred, which, in most instances, would be the state that properly rendered an action local unto itself. That said, a LARA-type regulation that precluded such jurisdiction in a given case could require that a plaintiff bring such an action in a jurisdiction other than the one that created it and properly rendered it local unto itself.

If these general principles, properly construed, have constitutional status, the question is whether any provision of the Constitution authorizes Congress to divest a state court of jurisdiction of a state law case that, under these principles, the state court had a sovereign prerogative to hear. Congress historically has deprived state courts of jurisdiction to hear certain federal actions-specifically, actions over which Congress has given exclusive jurisdiction to federal courts, and actions that Congress has enabled defendants to remove to federal court. In each of these instances, however, Congress has acted pursuant to its specific enumerated power under Articles I and III to constitute inferior federal tribunals ${ }^{258}$ and to make all necessary and proper laws for carrying that power into execution (including defining the jurisdiction of federal courts). ${ }^{259}$ The question is whether Congress has any corresponding enumerated power to divest state courts of jurisdiction in state law cases.

Unlike in the case of Congress commanding a state court to enforce a federal law, the Supremacy Clause does not in itself justify a congressional command that a state court is or is not a proper forum for the adjudication of a state law case. In Testa, the Supreme Court held that the Supremacy Clause overrode any general-law-based interest that a state might have in not enforcing a federal civil law for multiple damages. There are significant differences, however, between the situation that Testa addressed and federal regulation of state court jurisdiction in state law cases. Testa involved a state court's obligation to enforce a regulation of individuals that Congress had properly enacted pursuant to its enumerated powers. The question before the Court was whether a state court could refuse to enforce that otherwise valid and enforceable federal law. LARA does not impose any primary obligations upon individuals in their legal relations with others; it is a jurisdictional statute. The question for consideration is whether a federal law regulating a state court's jurisdiction in a state law case is a validly enacted one. The Supremacy Clause, as interpreted in Testa, does not speak to this question.

The power upon which Congress relied in enacting LARA was not the Supremacy Clause but its Article I power to regulate interstate commerce. ${ }^{260}$ In its findings, the House Judiciary Committee determined that state courts, in exercising their constitutional jurisdiction over personal injury claims, were

258. U.S. CoNsT. art. I, § 8, cl. 9; art. III, § l.

259. Id. art. I, \& 8, cl. $9,18$.

260. See id. art I, $\S 8$, cI. 3. 
substantially affecting interstate commerce. ${ }^{261}$ To say that the Commerce Clause empowers Congress to regulate state court jurisdiction is, of course, to beg the question whether general law principles set limits on congressional power to regulate state court jurisdiction absent a more specific textual override. Historically, public officials invoked general law principles to argue that Congress could not constitutionally regulate state court jurisdiction under an enumerated power. The kinds of constitutional provisions that public officials argued overrode general principles were provisions directly regulating the jurisdiction of federal courts and the duties of state courts, namely Article III and the Supremacy Clause. In other words, the question that the framework itself implicates is whether there are limits on the ways in which Congress properly may exercise its enumerated powers to regulate state court jurisdiction.

Employing the historical framework to limit the commerce power of Congress to divest state courts of jurisdiction of state law cases would jettison two potential constitutional problems with recognizing no such limits. The first problem relates to the theory of so-called "protective jurisdiction," a theory of uncertain constitutional validity in the eyes of the Supreme Court. ${ }^{262}$ Certain scholars have argued that, where necessary to protect federal interests, Congress may give federal courts jurisdiction ("protective jurisdiction") over purely state law actions that Article III does not otherwise include within its definition of the federal judicial power. ${ }^{263}$ Justice Frankfurter vigorously argued against the constitutionality of any such theory, ${ }^{264}$ and the Court has expressly reserved judgment on its constitutionality. ${ }^{265}$ If Justice Frankfurter is correct and Con-

261. H.R. Doc. No. 108-682, at 114-15 (2004).

Congress unquestionably has the authority to regulate economic activities that 'affect' interstate commerce, and forum shopping clearly has a substantial affect on interstate commerce by allowing opportunities for personal injury lawyers to exploit lax venue and forum non conveniens rules to pick and choose those courts with a reputation for consistently awarding near-limitless awards.

Id. (footnote omitted).

262. See Mesa v. California, 489 U.S. 121, 137 (1989) ("We have, in the past, not found the need to adopt a theory of 'protective jurisdiction' to support Art. III 'arising under' jurisdiction, and we do not see any need for doing so here ...." (citation omitted)); see also Verlinden B.V. v. Cent. Bank of Nig., 461 U.S. 480, 491 n.17 (1983) ("[W]e need not consider petitioner's alternative argument that the Act is constitutional as an aspect of so-called "protective jurisdiction."').

263. Professor Paul Mishkin articulated one of the first theories of protective jurisdiction in Paul Mishkin, The Federal "Question" in the District Courts, 53 Colum. L. REv. 157 (1953). On protective jurisdiction generally, see George D. Brown, Beyond Pennhurst-Protective Jurisdiction, the Eleventh Amendment, and the Power of Congress To Enlarge Federal Jurisdiction in Response to the Burger Court, 71 VA. L. Rev. 343 (1985), and William A. Fletcher, A Historical Interpretation of the Eleventh Amendment: A Narrow Construction of an Affirmative Grant of Jurisdiction Rather than a Prohibition Against Jurisdiction, 35 Stan. L. Rev. 1033 (1983).

264. See Textile Workers Union v. Lincoln Mills, 353 U.S. 448, 473 (1957) (Frankfurter, J., dissenting) ("Called 'protective jurisdiction,' the suggestion is that in any case for which Congress has the constitutional power to prescribe federal rules of decision and thus confer 'true' federal question jurisdiction, it may, without so doing, enact a jurisdictional statute, which will provide a federaI forum for the application of state statute and decisional law.").

265. See supra note 262. 
gress effectively has no Article I power to divest state courts of jurisdiction in favor of federal courts over state law cases, it may follow that Congress has no Article I power to transfer state law cases away from certain state courts to other state courts. ${ }^{266}$

The second constitutional question that the historical framework of analysis likely would jettison is whether Congress has authority to divest a state of authority to judicially enforce its own laws. In certain cases, a jurisdictional regulation like LARA would operate to divest state courts of jurisdiction to judicially enforce their own laws. LARA requires a plaintiff to file in the State where the person bringing suit resided at the time of filing or injury, where the injury occurred, or where the defendant's principal place of business is located. ${ }^{267}$ It is not difficult to imagine a case in which a state might constitutionally be able to apply its own law absent one of those indicia. The following state connections-alone or in combination-could give a state sufficient interest in a case to constitutionally apply its own law but would be insufficient for purposes of LARA: a natural-person defendant resides or is domiciled in the state; an artificial-person defendant is incorporated in the state; the plaintiff is domiciled but does not reside in the state; or some act relating to the lawsuit (other than the injury or primary circumstances giving rise to the claim) occurred in the state. ${ }^{268}$ Under LARA, a state could have a constitutional interest in applying its own law in a case but be congressionally precluded from enforcing it.

The Supreme Court has at least suggested that states generally have a constitutional interest in enforcing their own laws against individuals over whom they constitutionally may exercise jurisdiction. Recall Hamilton's statement that it is "a just principle that every government ought to possess the means of executing its own provisions by its own authority ...."269 This kind of language has found its way into the Supreme Court's constitutional jurisprudence. In Ponzi v. Fessenden, ${ }^{270}$ Chief Justice Taft wrote, "We live in the

266. It might be argued that there is a distinction between Congress divesting state courts of jurisdiction in favor of federal courts and Congress divesting state courts of jurisdiction in favor of other state courts. Article III specifically limits the jurisdiction of federal courts. Protective jurisdiction may be an improper regulation of commerce because it would give federal courts jurisdiction of cases to which the Article III judicial power does not extend. A state court made a proper forum over an action of which Congress has divested the courts of another state of jurisdiction would operate under no such constitutional limitation upon its jurisdiction. If that is so, could Congress give federal agencies jurisdiction of purely state law claims as a proper regulation of commerce in light of Article III and the interests of states? The purpose of this section is not to resolve these questions, it is simply to say that application of the historical framework of analysis would likely obviate the need to resolve many of them.

267. See supra notes 238-244 and accompanying text (describing requirements of statute).

268. See Restatement (SeCOND) of CONFlict of Laws $\$ 6$ (1971); see also Allstate Ins. Co. v. Hague, 449 U.S. 302, 312-13 (1981) (plurality opinion) ("[F]or a State's substantive law to be selected in a constitutionally permissihle manner, that State must have a significant contact or significant aggregation of contacts, creating state interests, such that choice of its law is neither arbitrary nor fundamentally unfair.").

269. The Federalist No. 80, supra note 88, at 537.

270. 258 U.S. 254 (1922). 
jurisdiction of two sovereignties, each having its own system of courts to declare and enforce its laws in common territory." ${ }^{271}$ In such a situation, Taft continued, " $[\mathrm{t}]$ he people for whose benefit these two systems are maintained are deeply interested that each system shall be effective and unhindered in its vindication of its laws." 272

There are good practical reasons for this. Consider a case in which a plaintiff would choose to enforce an action in State $A$, which would apply its own law as a rule of decision, but Congress requires the plaintiff to bring an action in State $B$, which also would apply the law of State $A$. In this case, Congress has deprived State $A$ of authority to enforce its own law. Ultimately, this means that a plaintiff may be required to litigate in a forum that has procedural laws that do not fit the underlying action well, ${ }^{273}$ and judges who are unaccountable to the state with governing law for their apphication of that law. Of course, it often happens that one state enforces an action governed by the laws of another. It may be that the plaintiff's chosen forum is the only forum that has jurisdiction over the defendant, or the plaintiff sees some other benefit to litigating in that forum. When Congress prohibits a state with governing law from enforcing that law, however, it deprives plaintiffs of the opportunity to pursue claims in the forum with procedural laws and remedies that may be best geared toward the effective enforcement of that law.

In sum, as regards the interests of a state made an unlawful forum for the adjudication of state law cases by Congress, the sovereign interests of the state that general jurisdictional principles recognized are reasonably clear. Most importantly, they recognized that the courts of a sovereign have jurisdiction, at a minimum, over the legal relations of its citizens or persons present within its territory. For Congress to divest state courts of jurisdiction over such cases would conflict with this general principle. Whether any specific constitutional provision overrides this principle is a more difficult question. There is no specific constitutional provision that authorizes Congress to regulate state court jurisdiction over state law cases, unless one rejects the notion that, at the time the Constitution became law, general law could have been understood to mark limitations on congressional power to regulate state court jurisdiction.

\section{LIMITATIONS OF THE POLITICAL SAFEGUARDS OF FEDERALISM}

Certain scholars have argued that, indeed, there are no effective judicially enforceable limits on congressional power vis-à-vis the states. ${ }^{274}$ Such scholars

27I. Id. at 259.

272. Id.

273. Under modern conflicts law, as under older conflicts paradigms, the forum state generally may apply its own procedural rules and practices. See Leflar, supra note 249 , at 331 . For an analysis of practical difficulties that can arise when a court enforces the substantive law of one state according to the procedural law of another state, see Anthony J. Bellia Jr., Federal Regulation of State Court Procedures, 110 YALE L. J. 947, 993-97 (200I).

274. See, e.g., Kramer, supra note 18. 
might argue in response to this analysis that we would do better simply to rely on the political safeguards of federalism, especially in light of the difficult questions that the historical framework of analysis generates. Professor Larry Kramer has argued, for example, that courts generally should not recognize judicially enforceable limitations on federal power for both historical and functional reasons. ${ }^{275}$ Historically, he claims that members of the Founding generation did not understand courts to have power to hold federal statutes unconstitutional as an exercise of power reserved to the States. ${ }^{276}$ Functionally, he claims that the party system, as it exists in the United States today, in fact operates to safeguard state sovereignty interests. ${ }^{277}$ Professors Sai Prakash and John Yoo have argued that both of these claims are in fact false. ${ }^{278}$ There is no need, for present purposes, to fully enter this debate. Suffice it to say, for purposes of congressional power to regulate state court jurisdiction, that (1) historically, many public officials of the Founding generation believed there to be judicially enforceable limitations on congressional power over state court jurisdiction; and (2) functionally, there are serious questions whether political safeguards of federalism are adequate to protect state sovereignty when federal laws operate to allocate power among state institutions.

First, as this Article demonstrates, many public officials of the Founding generation argued that Congress lacked power to require or even allow state courts to exercise jurisdiction over certain federal cases. Several state courts judicially enforced these limitations on federal power without so much as pausing to question whether they had authority to do so. At the very least, it is fair to conclude that several state courts deemed it constitutionally appropriate for them to abide by constitutional limitations on their jurisdiction (for example, the perceived limitation that Congress could not allow them to adjudicate federal criminal actions), notwithstanding congressional pronouncements to the contrary. Certain Supreme Court justices contemporaneously endorsed this position. Even Testa, in rejecting certain such constitutional limitations that state courts had enforced, did not rely on the political safeguards of federalism as a limitation on judicial review; it relied on the Supremacy Clause and inferences it drew therefrom. ${ }^{279}$

Second, there are serious questions whether, as a functional matter, the political safeguards of federalism actually safeguard state autonomy interests when federal laws operate to allocate power among state institutions. The literature arguing in favor of the political safeguards as the primary or sole safeguards of federalism rests upon two presumptions that may be unsound in the case of a statute like LARA. The first presumption is that federal statutes

275. See id.

276. See id. at 234-52.

277. Id. at 282. See generally id. at $278-87$.

278. See Saikrishma B. Prakash \& John C. Yoo, The Puzzling Persistence of Process-Based Federalism Theories, 79 Tex. L. Rev. 1459 (2001).

279. 330 U.S. $386,391-94$ (1947). 
regulate states with equal effect, or individuals. For example, the Supreme Court cases that Kramer criticizes, ${ }^{280}$ namely Lopez and Morrison, New York and Printz, and Seminole Tribe, involved federal statutes, respectively, creating crimes and private rights of action; requiring state institutions to enact or enforce federal regulatory programs; or subjecting states to suits for violating federally imposed duties. ${ }^{281}$ LARA is of a different mold. LARA is meant to divest state institutions of authority to act and thereby empower other state institutions to act. In effect, for instance, LARA would remove cases from states in which defendants do not have principal places of business to states in which defendants have principal places of business. This is a plain purpose of the bill. As is well known, some states are havens for corporations to have their principal places of business; others are not. If LARA has its intended effect, plaintiffs may properly bring more cases in, say, New York, and fewer cases in, say, Alabama. Accordingly, New York courts would be empowered to hear more transitory actions and Alabama courts would be empowered to hear fewer transitory actions, just as if Congress had provided that certain classes of cases must be brought in New York state courts and not in Alabama state courts. Thus, the presumption of the political safeguards literature that federal statutes affect the sovereignty of states in qualitatively equal ways is unsound with respect to a statute like LARA, if indeed it is ever sound.

The effect of this presumption falling away is significant. It means, first, that if the political safeguards of federalism are the sole safeguards of federalism, a block of states with sufficient voting power may, through their federal representatives, legitimately divest a state (or block of states with insufficient voting power) of power to exercise what historically many public officials viewed as sovereign prerogatives of each state. ${ }^{282}$ Taken to its logical conclusion, exclusive reliance on the political safeguards of federalism would recognize as legitimate a federal law simply abolishing the jurisdiction of the courts of the Commonwealth of Massachusetts.

A second presumption of the political safeguards literature is that the political safeguards retain a constant strength from before Congress passes a law affecting the authority of a state institution until after Congress does so. In other words, the political safeguards, it is presumed, render political actors as capable

280. See Kramer, supra note 18 , at 218 n.13, 227-29.

28I. In United States v. Lopez, 514 U.S. 549 (1995), the Court considered a federal statute prohibiting the possession of handguns near schools, and in United States v. Morrison, 529 U.S. 598 (1995), it considered a federal statute prohibiting certain acts of violence against women. In New York $v$. United States, 505 U.S. 144 (1992), the Court considered a federal statute requiring state legislatures generally to take title to or provide for the disposal of radioactive waste, and in Printz v. United States, 521 U.S. 898 (1997), it considered a federal statute requiring local sheriffs to conduct background checks on prospective handgun purchasers. In Seminole Tribe of Florida v. Florida, 517 U.S. 44 (1996), the Court considered whether Congress could abrogate state sovereign immunity generally in federal court through the exercise of an Article I enumerated power such as the Indian Commerce Clause.

282. Lynn Baker calls this "the problem of horizontal aggrandizement." Lynn A. Baker, Putting the Safeguards Back into the Political Safeguards of Federalism, 46 VILL. L. REv. 951, 961-63 (2001). 
of undoing a congressional regulation affecting state authority as they were to effect it. Whatever validity this presumption has in the case of a federal statute that regulates individuals, it is suspect in the case of a federal statute that disempowers state institutions. The impetus for LARA is a belief that some state institutions are acting badly by allowing large recoveries for plaintiffs while others are acting more worthily. In other words, if the statute passes, it will be because there is political will to reduce the ability of certain state courts to allow plaintiffs large damage awards in personal injury cases. Suppose the bill becomes law. Suppose, also, that ten years from now the culprit state courts against which Congress directed LARA have reformed the "errant" practices that provided the impetus for the statute. Would LARA be repealed? If it were, it seems Iess likely that it would be repealed because there was the political will to restore the lost jurisdiction of state courts than it would be repealed because there was the political will to further more direct individual interests that repeal would further. As Madison famously observed in The Federalist No. 10, "indirect and remote considerations," such as the individual liberty and other goods that state autonomy indirectly can effect, "will rarely prevail over the immediate interest which one party may find in disregarding the rights of another or the good of the whole." 283

The point is simply that direct and immediate interests generally shape political agendas, not indirect goods to be realized through preserving spheres of state governmental autonomy. If Congress regulates individuals in a way that interferes with state authority to act, perhaps it is a fair presumption that, as individual interests shift, it would be as qualitatively easy to undo the regulation as it was to initially enact it. On the other hand, if Congress regulates states in a way that interferes with state authority to act, it seems far less likely, as the interest that precipitated the regulation dissipates, that it will be as qualitatively easy to undo the regulation as it was to enact it. Unless deregulating state institutions would serve some immediate individual interests, restoring state authority to act would require the political will to do just that-to restore the indirect and remote benefits that less restricted state authority to act may generate. By Madison's hypothesis, such considerations will "rarely prevail." In effect, then, when by operation of the political safeguards of federalism Congress directly divests state institutions of power, it may leave behind political safeguards of federalism that, as a functional matter, are something less than they were before Congress acted.

\section{CONCLUSION}

The constitutionality of certain kinds of federal regulation of state court jurisdiction remains unsettled, including whether Congress may give state courts jurisdiction of federal criminal actions, or require that plaintiffs bring

283. The Federalist No. I0, at 60 (James Madison) (James E. Cooke ed., I96I). 
state law actions only in particular jurisdictions. Notwithstanding the political safeguards of federalism, historical arguments regarding congressional control of state court jurisdiction were premised on notions of dual sovereignty. Specifically, during the Founding period and the decades following it, constitutional arguments about congressional regulation of state court jurisdiction drew upon general law jurisdictional principles setting the bounds of jurisdiction between sovereigns. These principles accounted for the interests of both a forum state and the sovereign in or under the laws of which an action arose. Arguments that diverged from general jurisdictional principles relied on specific constitutional provisions interpreted to override them.

As applied to unresolved questions of congressional power today, this method of analysis generates some easy answers, but also identifies points of considerable difficulty, just as it did during Founding-era debates over the constitutional relationship between congressional power and state courts. A constitutional analysis that attempts to work through the "hard" questions will be more faithful to historical practice than an analysis that gives up on them in sole reliance on the political safeguards of federalism. As a functional matter, proper regard for the authority of state institutions may be a necessary safeguard against the political safeguards of federalism safeguarding away whatever strength they might have, at least in this context. 
